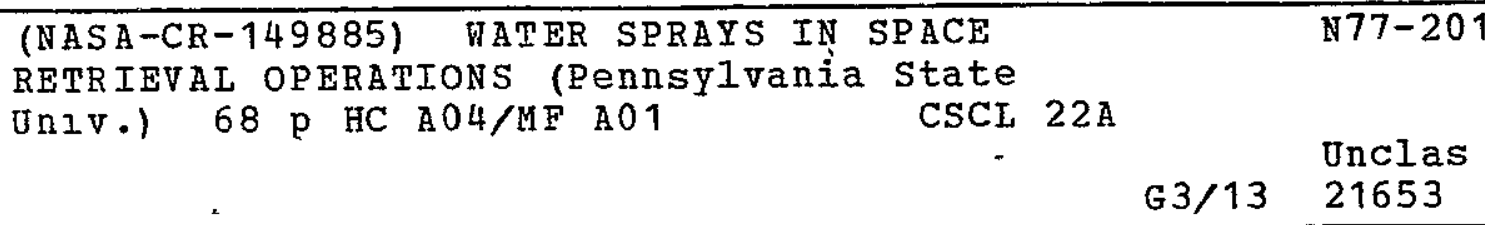

\title{
WATER SPRAYS IN SPACE RETRIEVAL OPERATIONS
}

\author{
BY \\ DOUGLAS C. FREESLAND \\ PROJECT ASSISTANT
}

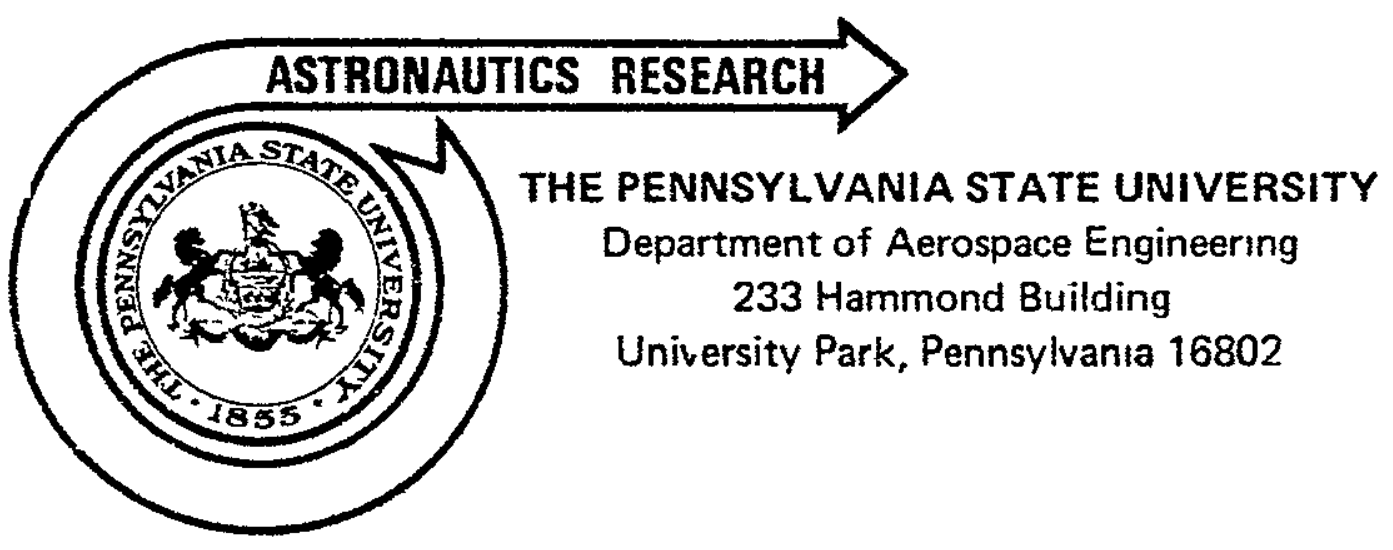

APRIL 1977

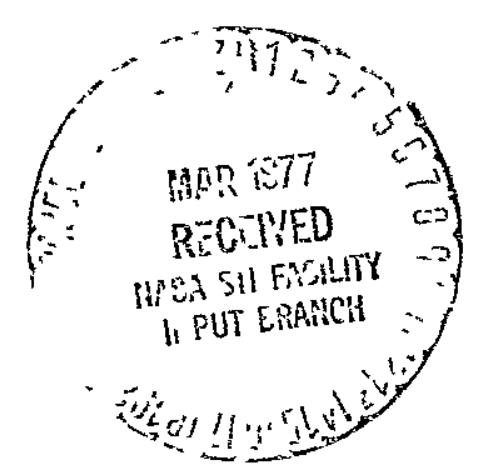


Recent experiments anvolvang 1ıquid jets exhausting into a vacuum have led to significant conclusions regardıng technıques for detumbling and despinning dısabled spacecraft durıng retrıeval operatıons. A fine water spray directed toward a tumbling or spinning object may quickly form ice over Its surface. The added mass of water will absorb angular momentum and slow the vehicle. As this ice sublimes it carrıes momentum away with $2 t$. Thus, a complete detumble or despin is possıble by simply sprayıng water at a disabled vehıcle. Experiments were conducted in a ground based vacuum chamber to determine physical propertıes of vater-ice in a space-like environment. Addıtıonal ıces, alcohol and ammonia, were also studied. An analytıcal analysis based on the conservation of angular momentum, resulted in despin performance parameters, l.e., total water mass requirements and despın tımes. The despın and retrieval of a disabled spacecraft was considered to illustrate a potential application of the water spray technique. 
TABLE OF CONTENTS

Page

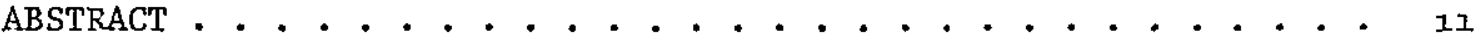

LIST OF TABLES . . . . . . . . . . . . . . . . . . . . . . . . 1V

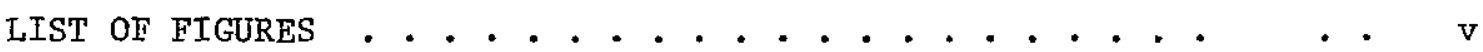

NOMENCLATURE . . . . . . . . . . . . . . . . . . . . . . . . . . . . . . V1

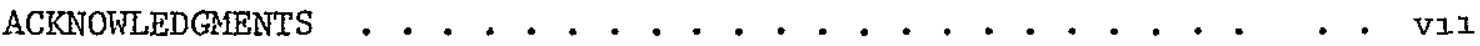

I. TNTRODUCTION . . . . . . . . . . . . . . . . . . . . . . . 1

1.1 Historical Development . . . . . . . . . . . . . . . . 1

1.2 Water Spray Technique . . . . . . . . . . . . . . 3

13 Purpose and Objectives . . . . . . . . . . . . 5

II. PREVIOUS INVESTIGATION . . . . • . . . . . . . . . . 6

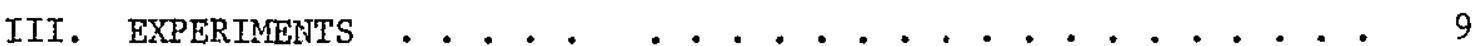

3.1 Purpose and Objectzves . . . . . . . . . . . . . . 9

3.2 Apparatus . . . . . . . . . . . . . . . . . . 9

3.3 Procedure . . . . . . . . . . . . . . . . . 12

3.4 Results . . . . . . . . . . . . . . . . . . . 12

IV. ANALYSES . . . . . . . . . . . . . . . . . . . . 19

4.1 Equations of Motion . . . . . . . . . . . . . . 19

4.2 Computer Simulation . . . . . . . . . . . . . . 23

43 Results . . . . . . . . . . . . . . . . . . 23

V. EXAMPLE APPLICATION- OSO - 5 RETRIEVAL • • • • • • • • • • . 28

5.1 Satellite Selection . . . . . . . . . . . . . 28

5.2 Satellite Passivation . . . . . . . . . . . . . 32

5.3 Satelizte Capture . . . . . . . . . . . . . . 36

5.4 Satelizte Stowage . . . . . . . . . . . . . . 40

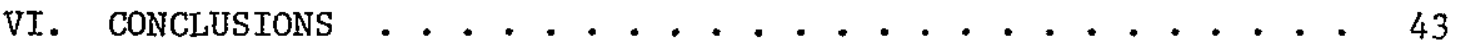

REFERENCES .............................. 45

APPENDIX A. Space Shuttle Payload Capability ........ 46

APPENDIX B. Satellites Wlthin the Shuttle Retrıeval Envelope • 50 


\section{LIST OF TABLES}

Table

Page

I Desıgn Crıterıa for a Satellıte Passıvatıon Scheme . . .

II The Stability of $1 \mathrm{~km}$ Ice Spheres in Circular Heliocentric Orbits at a Solar Distance of One Astronomical Unıt . . . 7

III Water-Ice Exponential Folding Tımes . . . . . . . 8

IV Candidate Sateliztes for Despın and Retrieval . . . . . 31

V OSO- 5 Mass and Inertıa Propertıes . . . . . . . . . 34

VI U.S. Satellites Within the Shuttle Retrieval Envelope • . 51

VII Forelgn Satellites Withın the Shuttle Retrueval Envelope . 54 
1 Water Spray Scheme ............... 4

2 Experımental Test Stand .............. 11

3 Experzmental Ice Formation ............ 13

4 Photographs Typical of Water-Ice Accumulating and Sublimating . . . . . . . . . . . . 15

5 Photographs Typical of Varzous Concentrations of Methanol in Water Accumulatıng and Sublımating . . . . . . 17

6 Angular Momentum Balance Mode1 . . . . . . . . . 21

7 Total Water Mass Requirements for a 98\% Reduction in Angular Momentum .. . . . . . . . . . . 24

8 Despin Times for a 98\% Reduction in Angular Momentum . . . 26

9 Typical Satellıte Despın Profıles . . . . . . . . . 27

10 Shuttle Retrieval Envelope . . . . . . . . . . 29

11 OSO - 5 Overall Dimensions ............. 33

12 OSO-5 Retrıeval Opexation . . . . . . . . . 35

13 Pallet Mounted Water Spray System . . . . . . . . . 37

14 Typical Despin Profiles for the 0so-5 Spacecraft . . . . 38

15 Total Water Mass Requirements for Despinnung the OSO-5

Spacecraft . . . . . . . . . . . . . . . 39

16 OSO- 5 Stowage for Reentry and Landing . . . . . . . . 41

17 Hydraulic Grappling Mechanism . . . . . . . . . . . . 42

18 Payload Mass Versus Circular Orbıtal Altitude - KSC

Launch, Delivery and Rendezvous........... 47

19 Payload Mass Versus Circular Orbital Altitude - VAFB Launch, Delivery and Rendezvous............ 48

20 Payload Mass Versus Inclination for Varıous Circular Orbıtal Altıtude, Delıvery and Rendezvous . . . . . . . 49 


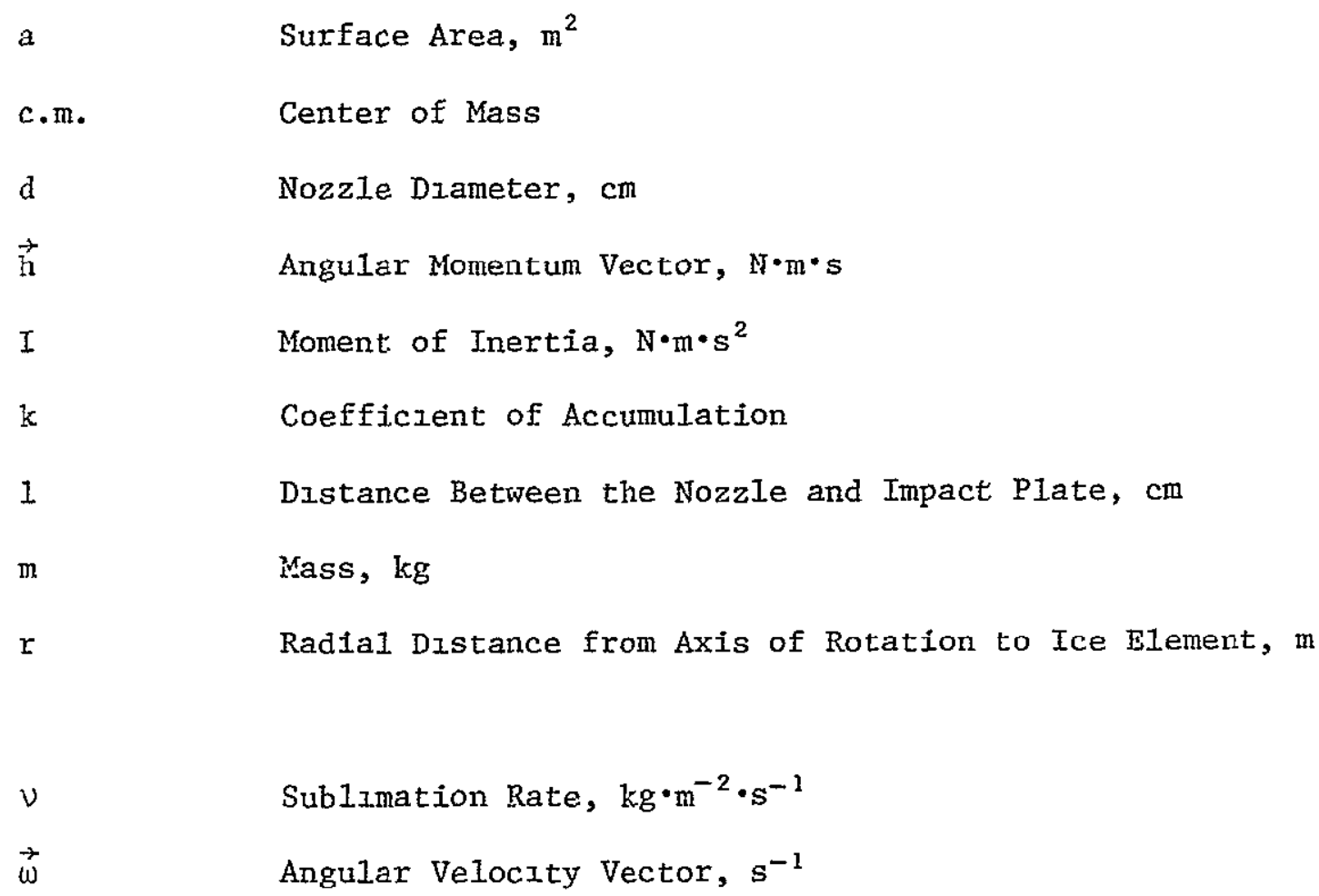




\section{ACKNOWLEDGMENTS}

The author wishes to express his gratitude and appreciation to Dr. Marshall H. Kaplan, Associate Professor of Aerospace Engineerıng, for his help in the development of the problem and invaluable aid during the course of this work. The author also wishes to acknowledge the Unzted States Alr Force for the opportunity to conduct this research through an educational delay. The work reported here was supported by NASA Grant NSG-7078. 
CHAPTER I

INTRODUCTION

With the advent of the space shuttle era retrieval of disabled spacecraft will become possıble. Prior to any attempted retrieval, however, vehıcle angular momentum must be nullified. A disabled spacecraft's angular momentum takes the form of ezther spinning or tumbling motion. This motion may be the result of a wildiy firing thruster, collision with another vehicle, or loss of attitude control. Hard docking by a manned retrieval craft is not possible because of the hazardous environment to which the crew would be exposed. Furthermore, devices which might be used for capturıng objects are not capable of grabbing something which is spinning or tumbling. There have been numerous techniques and hardware proposed to passivate, 1.e, detumble or despin, a disabled vehıcle. However, all of these devices represent complicated systems and are expensive and massive. A new technzque Involving liquid sprays has been concelved and appears to offer lower complexity, cost and mass.

\subsection{Hzstorıca1 Development}

Development of the water spray technique (WST) for space retrıeval operatıons has arısen out of a need for a sımple and ınexpensıve means of elımınating a disabled spacecraft's angular momentum. Addutıonal desıgn criteria are listed in Table $I$.

Early passivation schemes have included mechanical devices, nets, cables and rockets (1). Mechanical devices employ a synchronızed, rotatıng, dockıng mechanısm. Nets are envisıoned as catching 
Table I

Desıgn Crıteria for a Satellıte Passıvatıon Scheme (2)

1. Low development costs

2. Low recurrıng costs

3. Avaliable for operation at short notice

4. Within shuttle orbiter payload capability

5. Applicable to a wide range of vehıcle sizes

6. Should not damage tumbling spacecraft

7. Operated easily wzthout specialized crew

8. Hzgh relıabılity

9. Should pose no hazard to the retrueval spacecraft 
and entangling the tumbling spacecraft, arresting its motion by the net's attachment to the rescue vehicle or by rockets of varying sophistication. Cables are shot out toward the tumbling spacecraft, "harpoonıng" 1t, wrapp 1 g themselves around $1 t$, or otherwlse offerıng a means of providing a torque. Finally, rockets may be attached to the disabled vehicle to provide a detumbling or despinning torque. Each of these schemes have their drawbacks whıch do not satisfy the desıgn criteria.

Recent proposals have included the use of water jets to provide an external torque to a tumbling or spinnzng spacecraft (3). The concept Involves Impinging momentum to eliminate angular momentum. Here again, a complex system is required since proper alming and sequencing of the zmpinging water jet is necessary for a successful detumble. It was out of experimental investigation of this latter scheme that the WST was concelved.

LIquid jet experiments were carried out to Investigate the propertıes of jets impinging upon surfaces in vacuum. During some of these experiments it was realızed that water jets tend to form Ice on an object downstream. This experimental accident led M.H. Kaplan, at The Pennsylvanza State Unzversıty, to the concept of using the Ice advantageously (4).

\subsection{Water Spray Technıque}

A new technique for elzminating angular momentum involves the use of liquids, such as water, in a spray technzque. The Idea is to spray water at a tumbling or spinning object such that the water tends to accumulate on the target and form ice as illustrated In Figure 1. 


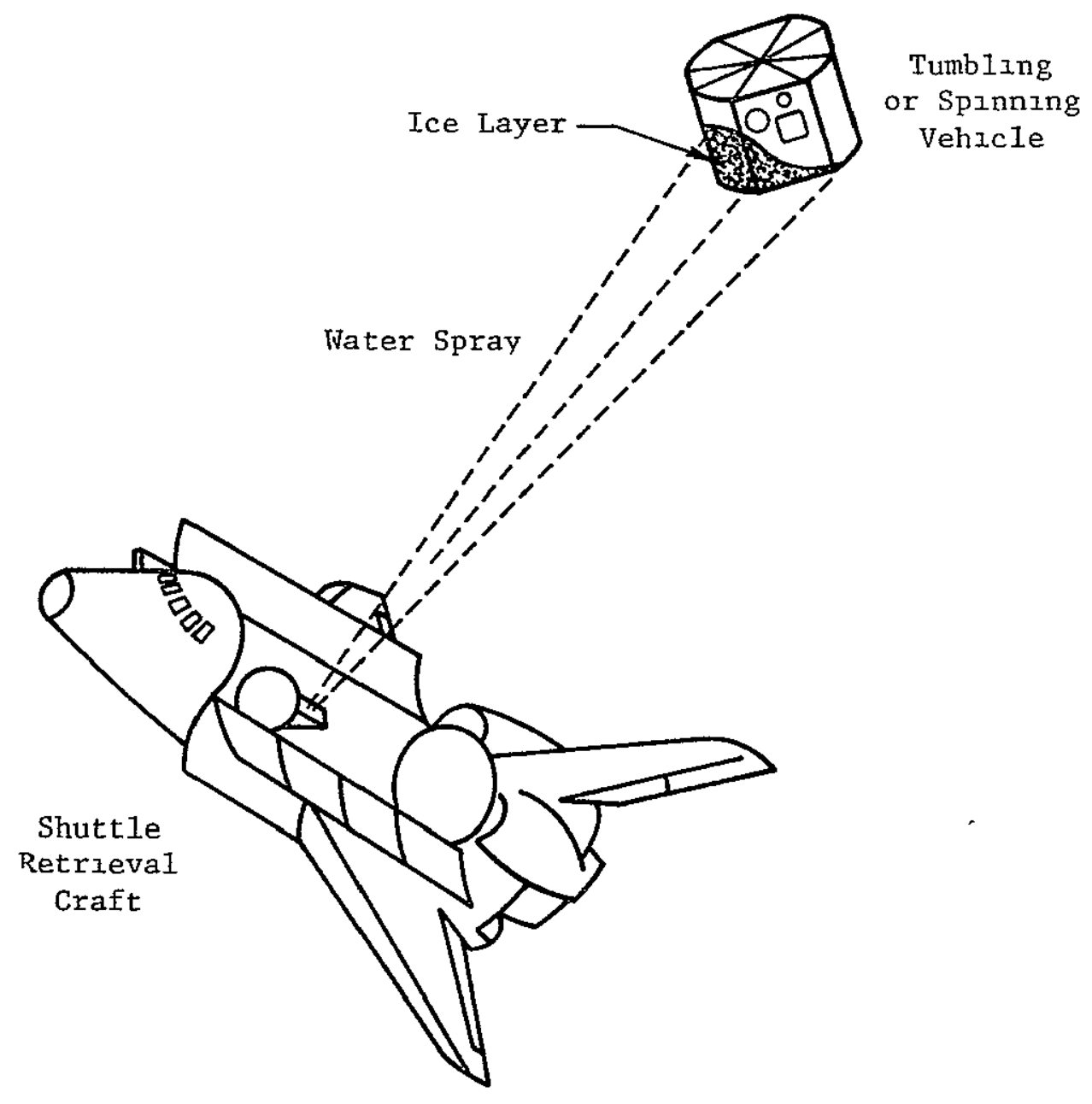

Fıgure 1 Water Spray Scheme 
This formation of Ice tends to absorb angular momentum. The concept has the obvious advantages of bypassing any hard docking requirements and beang simple in application. Very 1uttle hardware or logic is required. The shuttle crew simply points a nozzle at an object, turns on a valve and wayts for the object to despin or detumble. When a low enough angular rate 1 s observed of the object, the shuttle manipulator can then capture It and place It in the shuttle or carry out the prescribed refurbishment.

\subsection{Purpose and Objectıves}

It is the purpose of this investigation to examıne the WST. A serzes of experıments have been conducted to determine physical propertıes of water sprays exhausting into a vacuum. A computer model Is bullt which together with the experimental results, yields satellite despin performance parameters. To demonstrate an application of the WST, the selection and retrieval of an actual disabled spacecraft is considered. 
CHAPTER II

PREVIOUS INVESTIGATIONS

The use of water sprays as a technique to elimanate angular momentum was first introduced at the 27 th Congress of the International Astronautical Federatıon (5). A review of related work has revealed that the use of water sprays, as opposed to water jets, Is a new and origınal technıque for elımınating spacecraft angular momentum.

Other investıgators have done experiments and analytical work related to sublimation rates of varıous substances in space. However, very few quantitatıve analyses have been performed dealing with the sublimation of ice in a hard vacuum. Two investigations were found to be related to this work. One is analytıcal and the other experimental.

Watson (6) performed analyses on various ices in heliocentruc orbits. A simple energy balance was constructed across the surface of the ice from which the particle's lifetzme was calculated as a function of Its distance from the sun. Ices considered included water, anmonia, carbon dioxide and methane. The results are tabulated in Table II and indicate that water-ice has the longest lifetime while ammonza-ice sublumes about three tzmes as fast. Carbon dioxide-ice and methane-ice sublime at a rate twelve times faster than water-ice. These results were obtanned assuming that the ice particles were in circular helıocentric orbits at a distance of one astronomical unit from the sun. Effects related to the presence of the earth were not considered which resulted in lower energy absorbtıon and sublimation rates and longer lifetimes of the Ice spheres. 
Table II.

The Stability of $1 \mathrm{~km}$ Ice Spheres In Circular Heliocentric Orbits at a Solar Distance of One Astronomjcal Unit

\begin{tabular}{cc}
\hline Ice & Lufetume (years) \\
\hline Water & 530 \\
Ammonia & 167 \\
Carbon Dioxzde & 42 \\
Methane & 42 \\
\hline
\end{tabular}


By applying optical techniques to normal releases of water into space during Apollo Iunax missions, Sharma (7) has determaned sıze hıstorıes of micron size ıce particles. Thıs experıment determined that the radius of a particle of water-ice in a near earth orbit (650 km altıtude) wall decrease by a factor of $1 / \mathrm{e}$ in 1100 seconds, I.e., exponentzal folding tzme of 1100 seconds. For particles located at distances greater than 10 earth radil, where the . equilibrium temperatures of the water-ıce are so low that emission of radiatzon dominates sublimation and partıcle lifetımes increase considerably, the exponentıal folding time is $1.0 \times 10^{5}$ seconds. These results are listed in Table III. Since the shuttle will operate in a near earth environnent and since the experimental results were from direct observation, an exponential folding time of 1100 seconds has been used in the analytical development of the WST.

Table III

Water-Ice Exponential Folding TImes (7)

\begin{tabular}{c|cc}
\hline & Near Earth $(650 \mathrm{~km}$ A.ItItude) \\
$\begin{array}{c}\text { Cislunar Space } \\
\text { e-Folding Time }\end{array}$ & $\begin{array}{c}\text { e-Folding Time } \\
(\mathrm{sec})\end{array}$ & $\begin{array}{c}\text { Uncertaınty Range } \\
(\mathrm{sec})\end{array}$ \\
\hline $1 \times 10^{5} \ldots$ & 1100 & $1200-200$ \\
\hline
\end{tabular}


CHAPTER III

EXPERIMENTS

Experiments were conducted to determine physıcal properties of water sprays in a space-like environment. Additive and dispersion effects were also considered. The results, although basıcally qualItative, support the conclusions of Vatson (6) and Sharma (7).

\subsection{Purpose and Objectives}

A serıes of experiments were conducted in a small vacuum chamber to determine the physical properties of vater sprays in a space-like environment. Physical properties of Interest Included the accumulation and sublimation rates of water-ıce as we11 as the effect of ice layer thickness on sublimation rates. Several addıtional parameters were studied and include:

1. Dispersion effects, I.e., the ratio of impact cross sectional area to nozzle cross-sectional area.

2. The effects of ammonia and alcohol as additives on the physical properties of the water spray.

\subsection{Apparatus}

The water spray experiments were conducted in a sma11 vacuum faciluty at The Pennsylvania State UnIversity. The facllity consisted of four maln elements: chamber, pumps, pressure sensors and test stand.

The vacuum chamber used was a stalnless steel cylindrical structure with a diameter of $0.97 \mathrm{~m}$ and length of $2.11 \mathrm{~m}$, enclosing 
a volume of $1.56 \mathrm{~m}^{3}$. It was equipped with three plexıglas viewing ports as well as a stannless steel end plate through which all electrical, mechanical and fluldıc interfaces were made. The chamber was evacuated continuously by a $41 \mathrm{~cm}$ ringjet'booster pump and a Stokes 412H mechanical vacuum pump. This combination of pumps is capable of producing pressures on the order of $10^{-4}$ torr.

Two types of pressure sensors were employed durnng the course of the experiments. The first was a Philips Gauge. This type of pressure sensor measures the lonızation potentıal between a palr of electrodes, converting this into a pressure reading. The second type of pressure sensor used was a MKS Baratron. Thls device measured pressure dırectly, ı.e., force per unIt area.

The test stand nounted inside the chamber nncluded a nozzle, Impact plate and reference grid as illustrated In Figure 2. A staınless steel curcular tube with inside diameter, $d=5.54 \times 10^{-2} \mathrm{~cm}$, was used as a nozzle. The nozzle end was cut perpendicular to the tube's axis of symmetry with a cross-sectional area of $2.41 \times 10^{-3} \mathrm{~cm}^{2}$. Water was supplied to the nozzle from a reservoir open to atmospheric pressure. The Impact plate consisted of a rigid aluminum plate also positioned perpendicular to the nozzle's axis of symmetry. The plate was mounted on a moveable base which could be located a distance 1 , from $5.0 \mathrm{~cm}$ to $16.0 \mathrm{~cm}$ downstream of the nozzle. Aligned parallel to the nozzle's axıs of symmetry, was the reference grid, an aluminum plate with a $0.64 \mathrm{~cm}$ grad etched on 1 ts surface. 


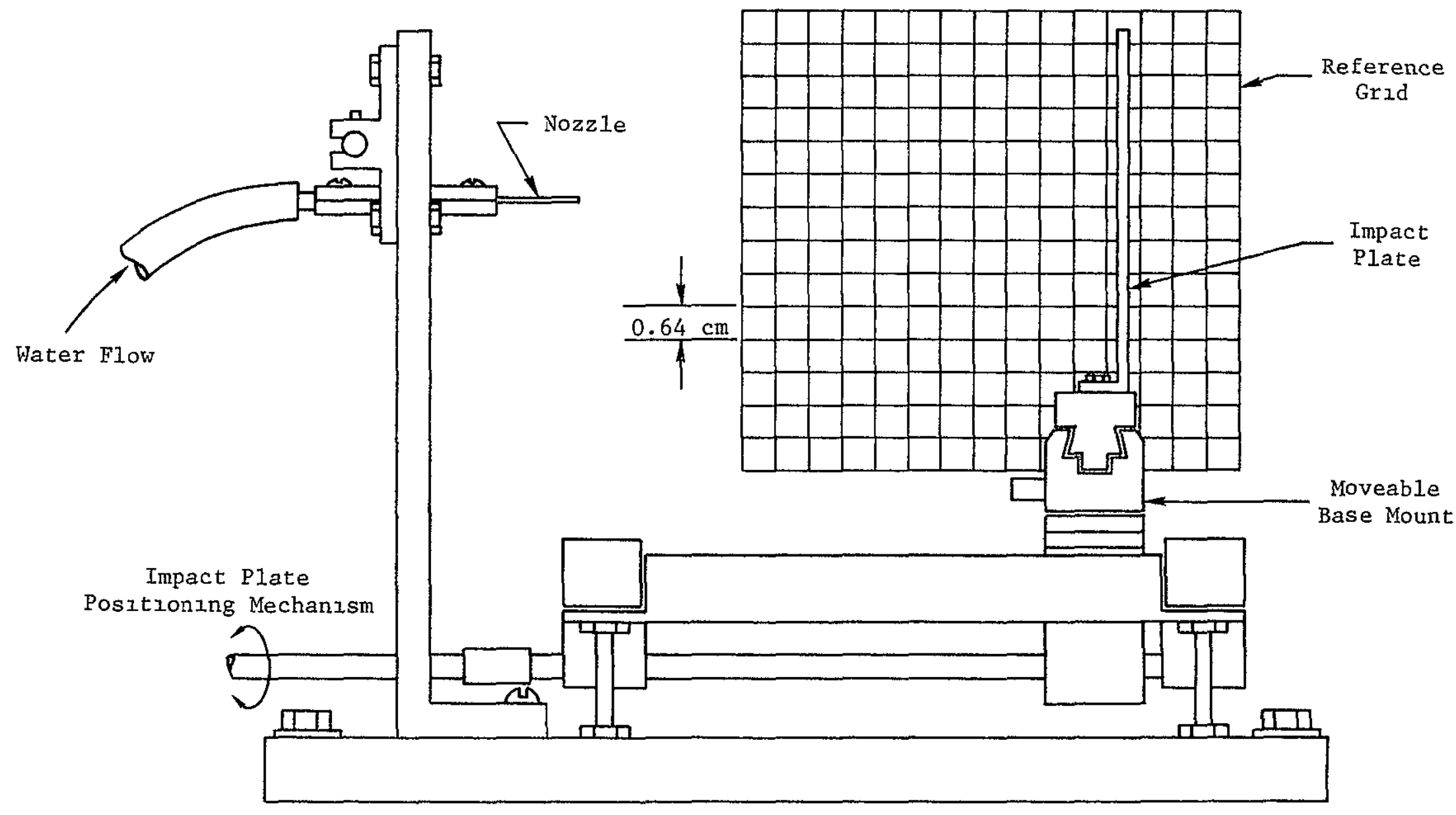




\subsection{Procedure}

In order to satısfy experimental purpose and objectıves, numerous runs were made using water and concentrations of ammonia and alcohol. A typical run could be dıvided into four phases: pump down, Ice accumulation, Ice sublimation and pump up. Inztially the vacuum chamber was at atmospheric pressure. Once the chamber was properly sealed, the mechanzcal and dxffuszon pumps were used to produce the vacuum. After several hours, the pressure in the chamber had reached a sufficiently low value, on the order of $10^{-4}$ torr. At this time a valve was quzckly opened and closed allowing less than 0.005 liters of water to flow from the reservour through the nozzle, ampinging upon the Impact plate as Illustrated in Figure 3. Upon Impact the water Imnediately froze, forming a thin layer of ice. As sublimation took place, the nass of the Ice was recorded as a function of time. With the sublumation complete, nitrogen was pumped into the chamber to return it to atmospherzc pressure. A] so shorn in Figure 3 is the scattered spray due to nozzle end effects. This phenomenon wall be dascussed further in the proceeding section.

\subsection{ResuIts}

Szgniflcant results were obtazned for water exhausting into a vacuum. As water was injected into the chamber, it Immediately froze due to the cooling which accompanies rapıd expansion. The resulting stream of tiny ice particles impinged upon the Impact plate forming a thin layer of 1ce. Accompanying this lce formation was a temporary pressure Increase of approxımately three orders of magnatude. This Increase was due to the limzted chamber volume and 


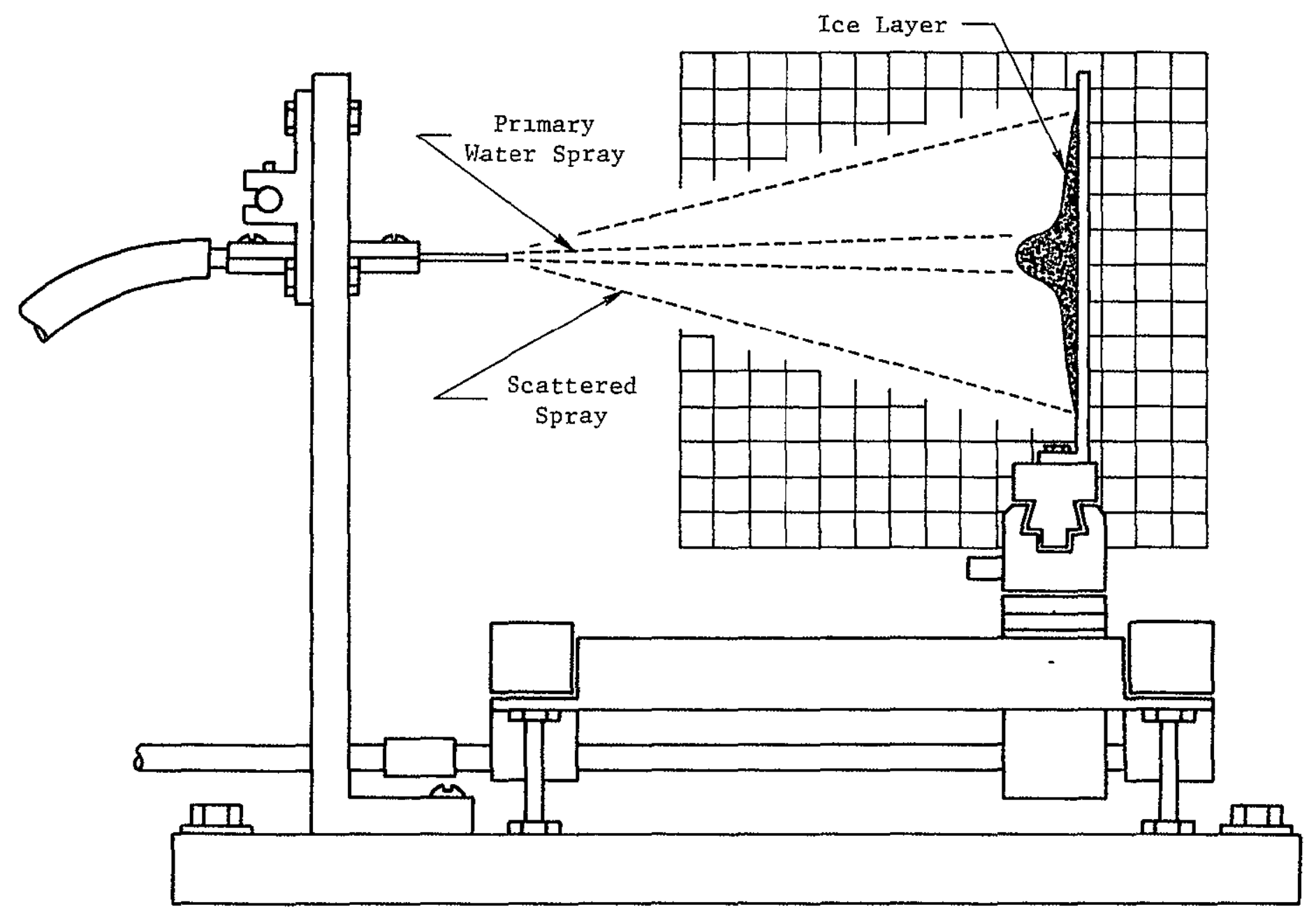

Figure 3. Experimental Ice Formation 
pumping capacity, and was sufficzent to cause a phase change in the accumulating ıce. Inıtıally, the accumulating ice was a rime 1ce, i.e., frosty and opaque. As the pressure increased this turned to a clear ıce, I.e., smooth and translucent. After accumulation was complete the Incoming water was shut off. Within 240 seconds the pressure had returned to Its low value and the Ice had reverted back to Its rime phase. Photographs typıcal of water-Ice accumulating and sublimating are presented in Figure 4. The pressure Increase experienced in the laboratory facility should not adversly effect the operational application of the WST in space.

As the water was injected Into the chamber It separated into two sprays primary and scattered. It is belleved that the scattered spray was due to nozzle end effects which may be eliminated through proper nozzle desıgn. This spray resulted in a thın layer of zce forming on the impact plate. In contrast, the primary spray resulted In a thicker layer of Ice belng formed For an $1 / \mathrm{d}$ of 269 , the ratıo of Impact cross-sectional area to nozzle cross-sectional area was 530 .

On the average, It took 2700 seconds for $0.002 \mathrm{~kg}$ of water-1ce to sublime. However, several factors influenced the sublimation rate. The thinner the initial layer of zce the quicker it sublimed. This is seen In that the thin layer of ice due to the scattered spray sublimed faster than did the thicker layer fron the primary spray. In addition, lce layers with larger surface areas also sublimed faster. The background pressure also effected the sublimation in that the higher the pressure the lower the sublimation rate. The effects of a11 these factors suggest that the sublimation rate is not a constant but varıes with layer thıckness, surface area, background pressure 


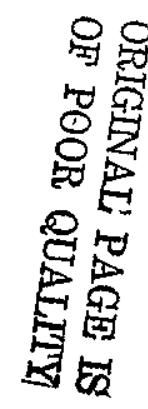

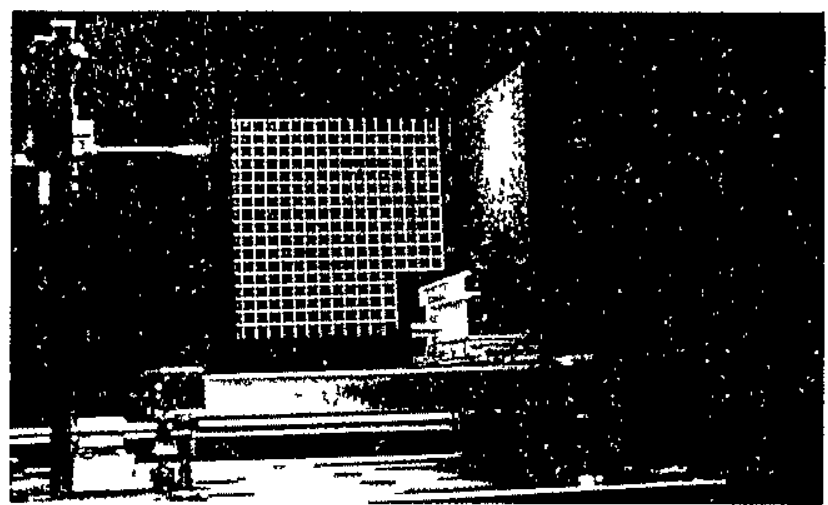

a. Water Spray Inıtıated at Time, $t=-5.0$ Seconds.

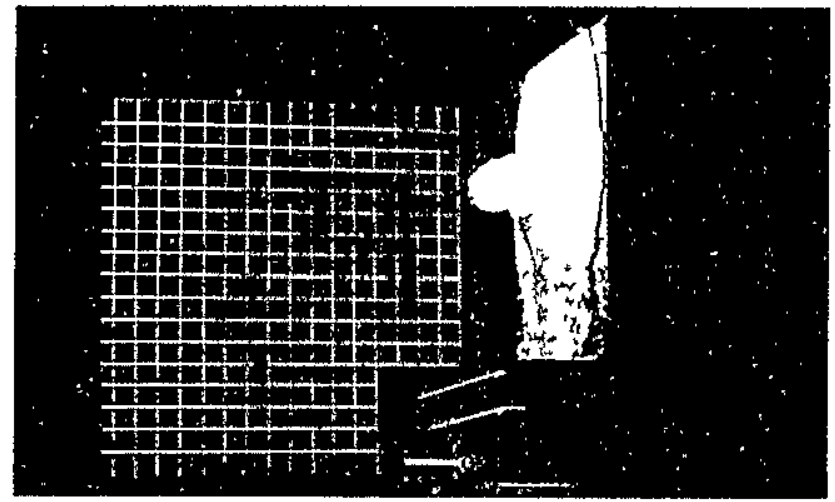

c. Sublimation Continuing at Time, $t=1800$ Seconds.

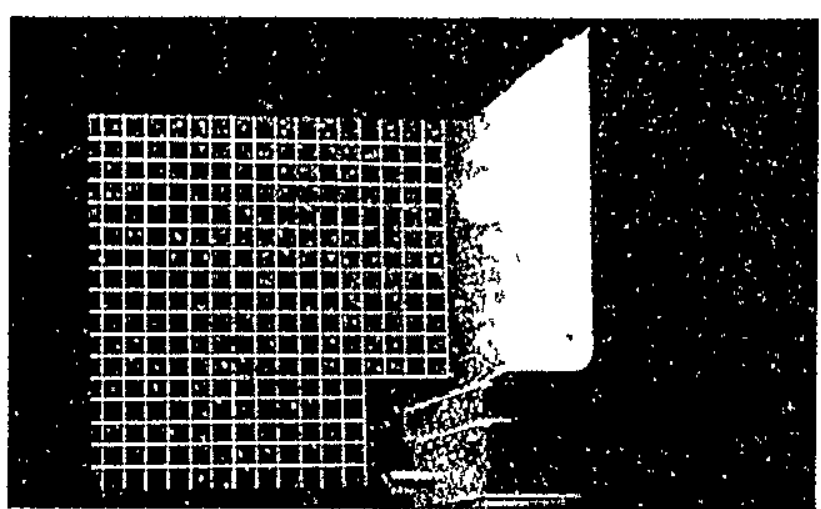

b. Accumulation Complete at Tıme, $t=0.0$ Seconds.

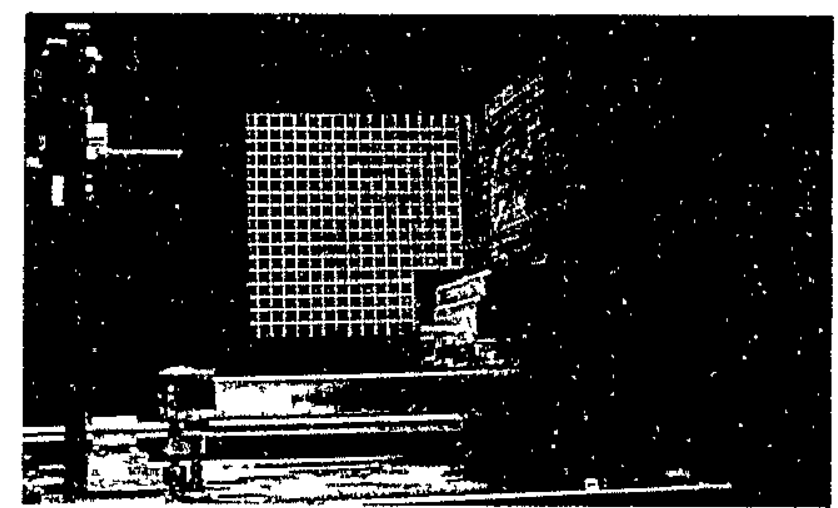

d. Sublimation Complete at Time, $t=2700$ Seconds. 
and temperature.

Additional tests were conducted using $50 \%$ and $33 \%$ concentrations of ammonıa hydroxıde in water as the working fluzd Problems were encountered with these tests, however, as the ammonia hydroxide reacted with the copper tubing which connected the reservour to the nozzle. The resulting copper ammonia lon contaminated the solution, tinting it blue. Upon release into the chamber the solution froze with a translucent slushy appearance. Agaln, as the pressure was reduced a phase change occurred, changing the clear lce to rime Ice. As sublimation took place, cublc milizmeter size particles of 1ce seemed to explode from the surface of the nazn Ice formation and cling to the Insides of the vacuum chamber. This might be explained by the paramagnetism of the copper ammonia 1on. Consequent1y, the sublimation rate was not observable.

Tests were also conducted using various concentrations of methanol in water, as 11 lustrated in Figure 5. A $100 \%$ concentration of methanol was exhausted into the chamber, evaporating as fast as it was pumped in; no lce was formed. At a concentratzon of $50 \%$ the spray formed 1Iquid drops on the Impact plate which froze after 37 seconds. Sımılar results were obtained usıng a $33 \%$ concentratıon. At this concentration liquid drops formed which took 120 seconds to freeze In both cases it took approxımately 900 seconds for the small drops to sublime. At $20 \%$ and $10 \%$ concentrations, the spray formed a slush upon contact with the Impact plate. After 1500 seconds the slush had solzdifzed, turning into an opaque rime ice. At a concentration of $10 \%$ It took 1050 seconds for $0.002 \mathrm{~kg}$ of ice to sublime.

Although only qualitative in nature, these results compare 


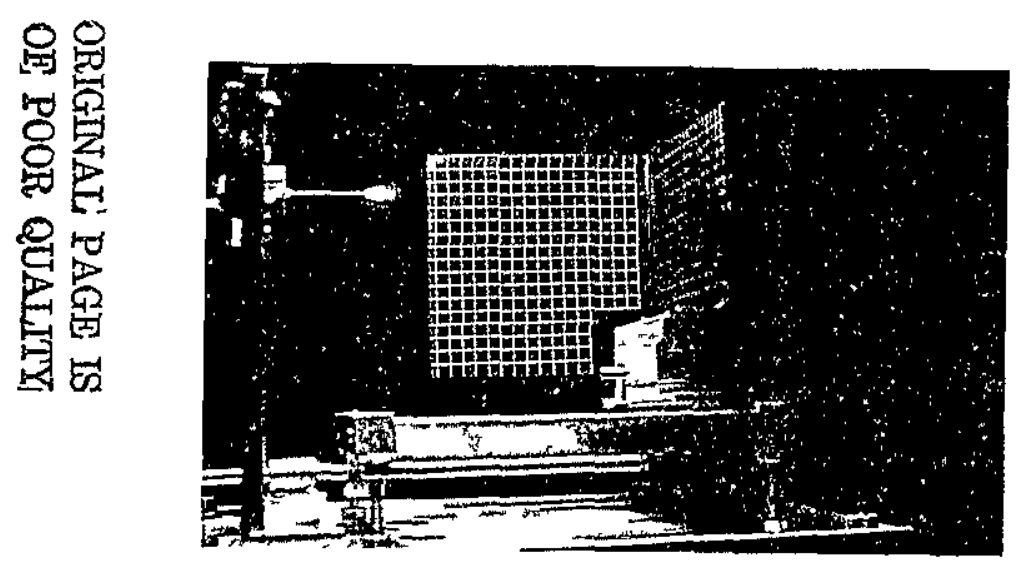

a. Complete Evaporatıon, No Ice Formatıon at $100 \%$ Concentration.

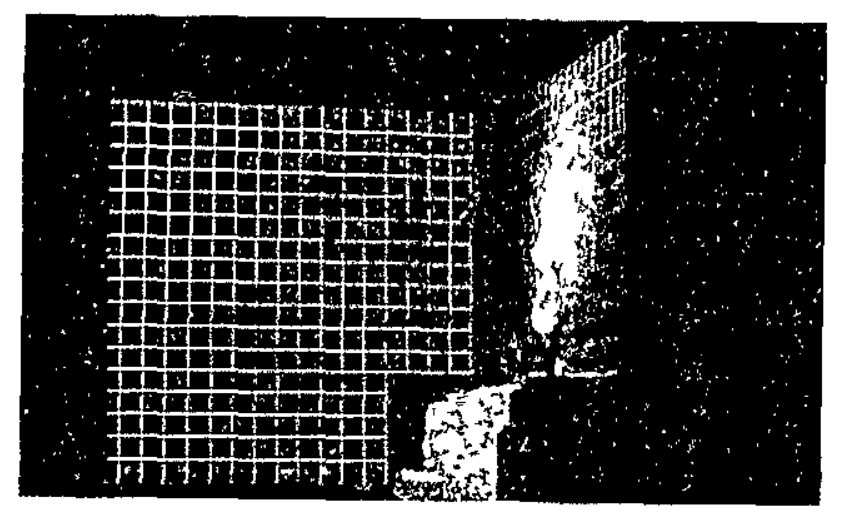

c. Slush Formation at $20 \%$ Concentration, Time, $t=30$ Seconds.

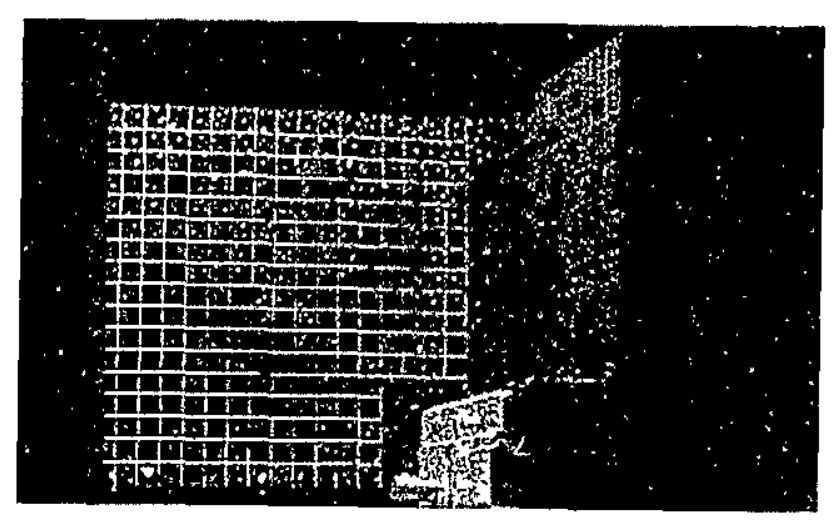

b. Liquid Drop Formation at $50 \%$ Concentration.

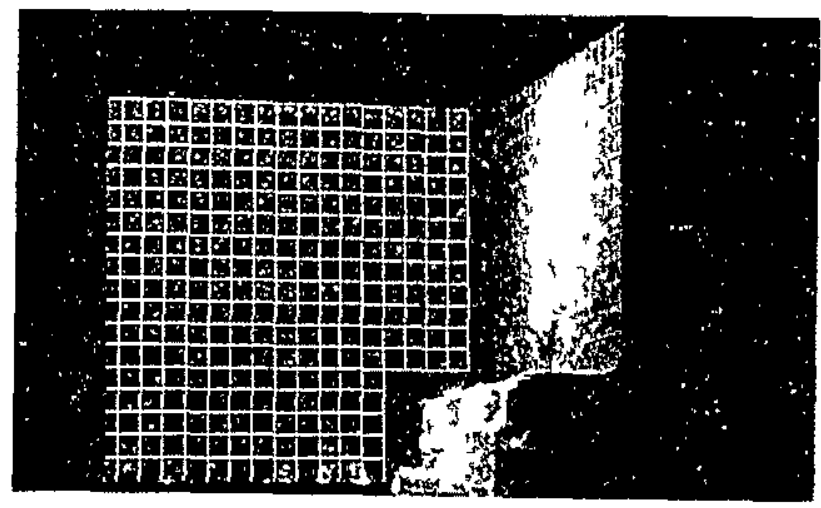

d. Solidified Rime Ice at $20 \%$ Concentration, Time, $t=1500$ Seconds. 
favorably with prevıous Investigations. The sublimation rate determined for water is supportive of the 1100 second exponential folding tıme observed by Sharma (7). The effect of additives, such as ammonia and alcohol, is to increase the sublimation rate as observed by Watson $(6)$. 
CHAPTER IV

ANALYSES

The analyses of the WST were divided Into two parts. First to be consıdered were the equations of motıon for a vehıcle being despun or detumbled via the WST. Secondly, these equations of motion were programmed on a digital computer to simulate the despin operation. Results of the analyses are presented and Include water mass requirements, despın tımes and despin profiles.

\subsection{Equations of Motion}

The equations of motion for a spacecraft being detumbled or despun by means of the WST, were derived using both a control volume analysıs and an angular momentum balance. A rigorous derivation of the equations of motzon following the control volume analysis of Grubın (8), resulted in a set of first order nonlınear differential equations coupled in $\vec{\omega}$. These equations, were most general and applied to any arbitrary vehicle with arbitrary components of angular velocity. However, Included in the resulting equations were integrations over the tumbling vehlcle's surface which, except in the case of simple geometries, would have been difficult to solve and provided very 11ttle Insight Into the problem. For these reasons, the control volume approach was excluded from further consideration.

In order to provide more physical insight into the problem, an angular momentum balance was performed (9). The water spray was assumed to possess low momentum, imparting negligible torque to the spinning vehicle. Furthermore, it was assumed that sublimation 
occurred radially such that the net torque was negligible. An additional simplification was to assume that a spacecraft's complex geometry may be represented by an equivalent cylindracal body. The equivalent cylındrical body has the same moment of Inertia about the spın axıs and same surface area as the origınal spacecraft. Figure 6 lllustrates the angular momentum balance model in whlch a low momentum water spray impinges upon the curcumference of a cylinder spınning about Its axis of symmetery. A than ice layer forms over Its surface whych sublimes, carryıng away momentum with It. The momentum balance between the vehıcle's angular momentum $h_{v}$ and the zce's momentum $h_{w}$ can be written in differential form as

$$
-d h_{v}=d h_{w}
$$

The vehicle's angular momentum is expressed as

$$
\mathrm{h}_{\mathrm{v}}=\mathrm{I} \omega
$$

where I is the vehicle's moment of inertia about the axis of rotation and $\omega$ Is Its corresponding angular velocity. Assuming I to be constant and differentiating

$$
\mathrm{dh}_{\mathrm{v}}=\mathrm{Id} \mathrm{d}
$$

For the water making up the thin lce layer a11ustrated In Figure 6, Its angular momentum may be expressed in differential form as

$$
\mathrm{dh}_{\mathrm{w}}=\mathrm{r}^{2} \omega \mathrm{dm}
$$

with $r$ being the perpendicular distance from the axis of rotation to the lce with mass $m$. Substitution of equations (3) and (4) into (1) 


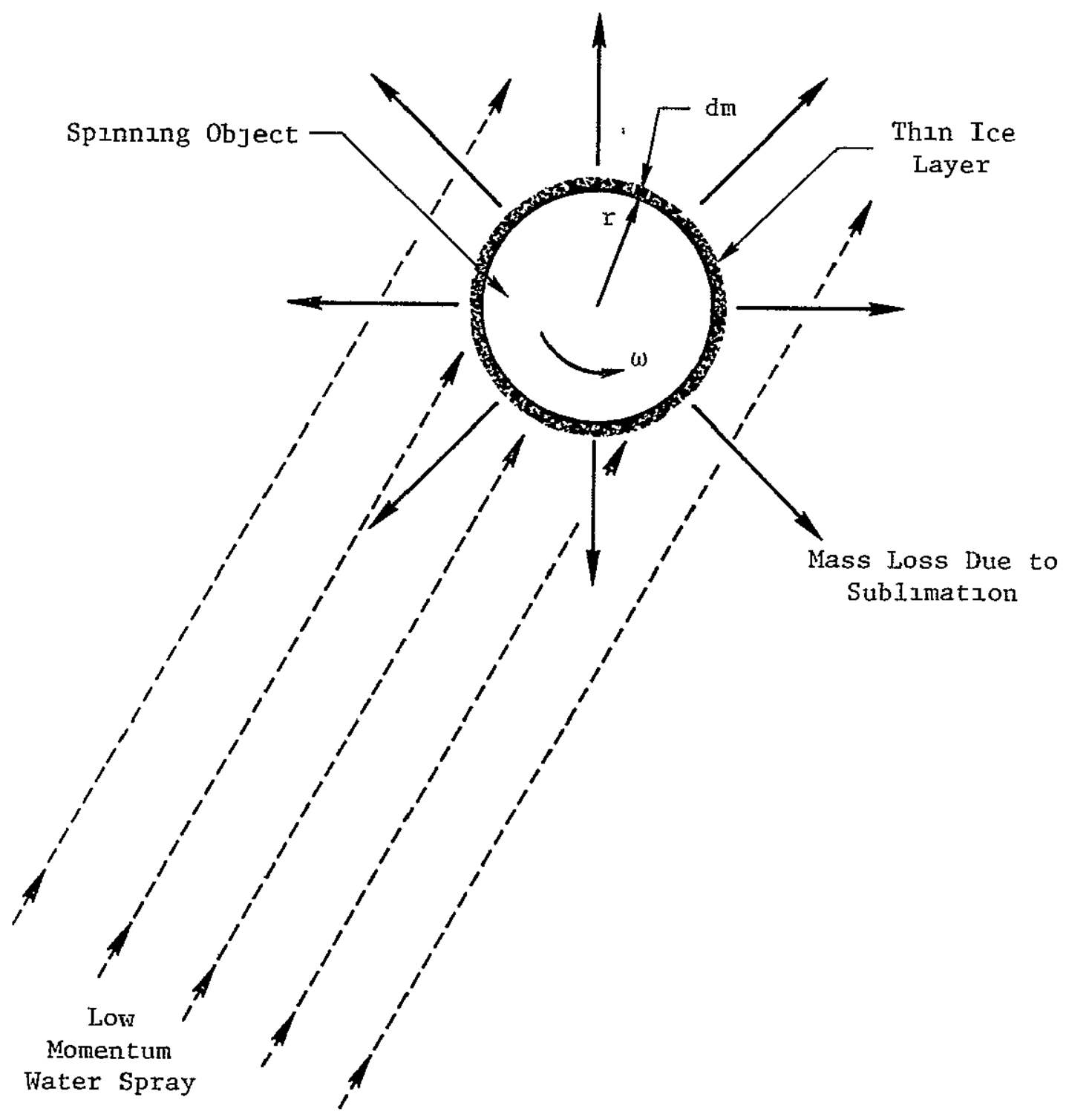

Figure 6. Angular Momentum Balance Model. 
yields the dzfferential form of the angular momentum balance

$$
-I d \omega=r^{2} \omega d m
$$

Integrating

$$
-\left.I \operatorname{Ln} \omega\right|_{\omega_{i}} ^{\omega_{f}}=r^{2} \mathrm{~m}
$$

where $\omega_{i}$ and $\omega_{f}$ are the initıal and flnal spin rates respectively. Solving for $\mathrm{m}$

$$
-\frac{I}{r^{2}} \operatorname{Ln} \frac{\omega_{f}}{\omega_{i}}=m
$$

This equation expresses the mass of water required to stick to the vehicle as a function of Its inctial and final spin rates. Note that the minus sign Insures that $\omega_{f}$ will always be less than $\omega_{1}$. Only a fraction of the water being sprayed from the retrzeval craft actualiy stıcks to the spinning vehıcle. Thus, the total water mass sprayed $\eta_{t}$ may be expressed as

$$
\mathrm{m}=\mathrm{km}
$$

where $k$ is a coefficient of accumulation, 1.e., the ratio of total water mass sprayed to that which sticks to the target, with values

$$
0 \leq k \leq 1
$$

Obviously the crew of the shuttle must wait untll the lce sublimes In order to actually capture the object. Using an average value for the sublimation rate $\nu$, the time $t$ for the Ice with surface area a to sublime is

$$
t=\frac{m}{v a}
$$




\subsection{Computer Simulation}

A computer program was written to simulate the WST in operation. The program consisted of modeling the angular momentum balance developed in the previous section on an IBM 370/I68 digital computer. It has been assumed that each satellite had an initial spin rate of $30 \mathrm{rpm}$ and 1 ts inertıa can be estımated from 1 ts mass. It was also assumed that the flow rate of water to the object was equal to the sublimation rate. The final spin rate was choosen to be $0.6 \mathrm{rpm}$, a $98 \%$ reduction in angular momentum. The program calculated total water mass requirements and despin times as a function of satellite mass and coefficient of accumulatıon Typıcal despın profıles for a $200 \mathrm{~kg}$ satellite were also calculated. The complete results are presented in the following section.

\subsection{Results}

Satelizte despin performance parameters have resulted from the computer simulated water spray retrieval operation. Of primary Interest were the total water mass requirements for a complete despin. Figure 7 is a graph of total water mass requirements as a function of satellite mass and coefficlent of accumulation. Assuming a realıstic value for $k$ to be between 0.05 and 0.5 , for a spacecraft up to about $800 \mathrm{~kg}$ the amount of water required to despin it is well wathin the shuttle payload capabilities outlined in Appendix A. These water mass requirements are of the same order of magnitude as those estimated for the water jet technique (2).

An additional consideration is the time required to despin an object. Obviously the crew of the shuttle must wait until the water 


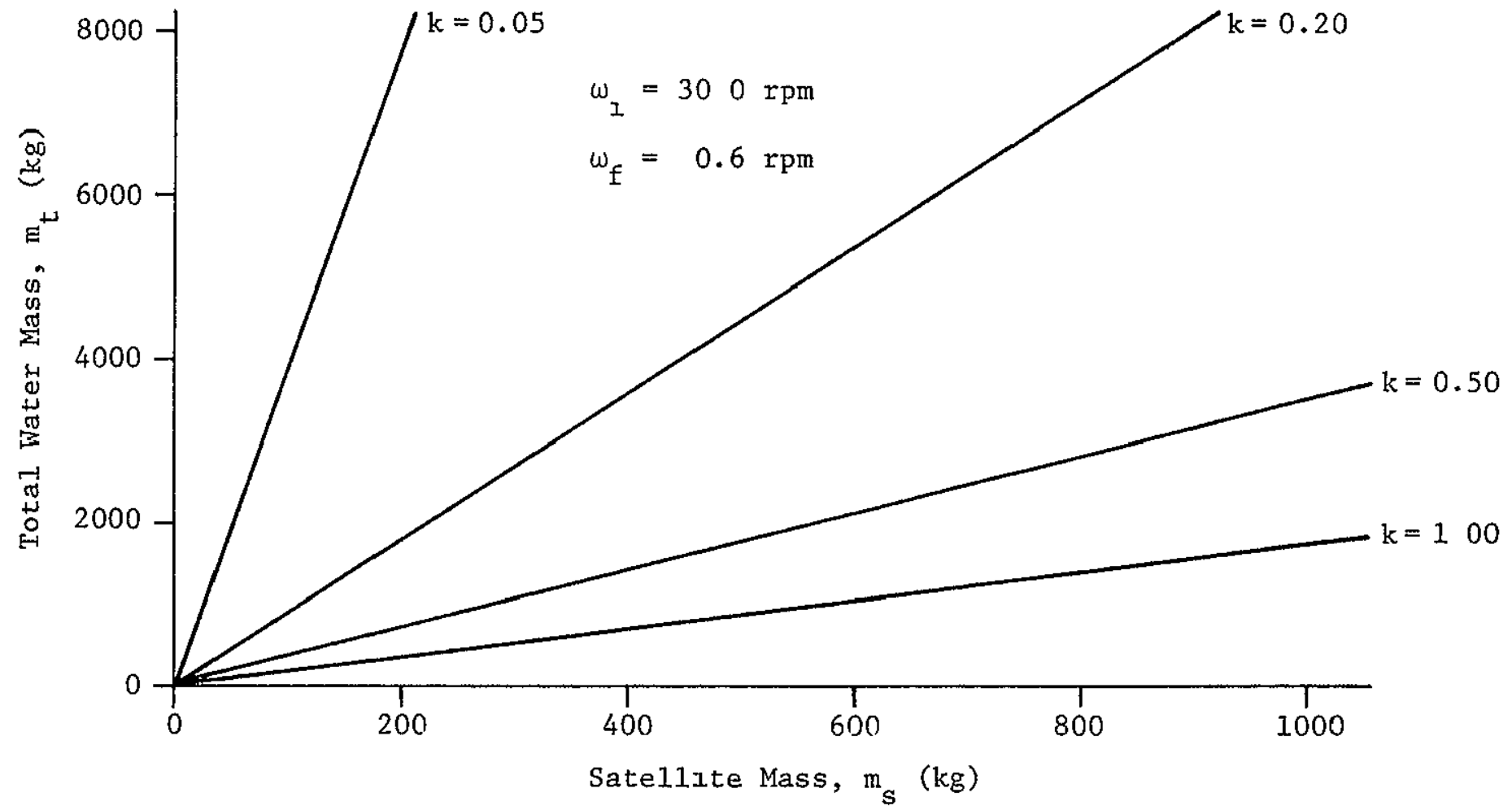

Figure 7 Total llater Mass Requirements for a $98 \%$ Reduction in Angular Momentum. 
sublimes in order to actually capture an object. This is why the sublimation rates are critical with regard to this technique. Figure 8 summarzzes the results of calculations of despin times Sublimation rates used are discussed in the preceeding chapter. Assuming a coefficent of accumulation between 0.05 and 0.5 , the despin tzme required for sateliltes up to $800 \mathrm{~kg}$ mass ranges from a few minutes to about two hours.

Figure 9 shows some typical despin profiles for different coefficients of accumulation. In all cases the despin profile is exponentıa1. Thıs particular figure is for a satellıte of $200 \mathrm{~kg}$ mass. 


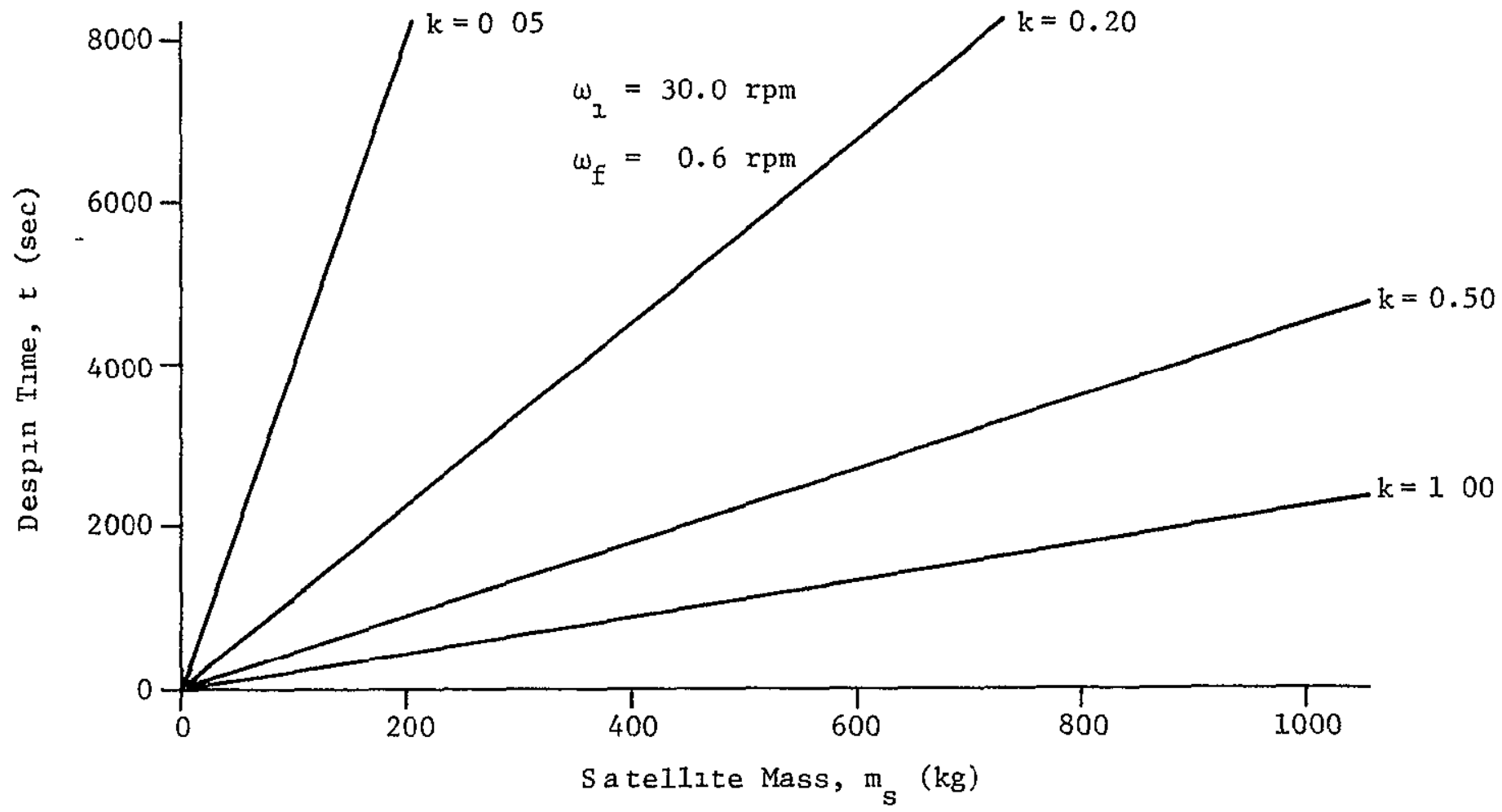

Figure 8 Despin Times for a 98\% Reduction in Angulax Momentum. 


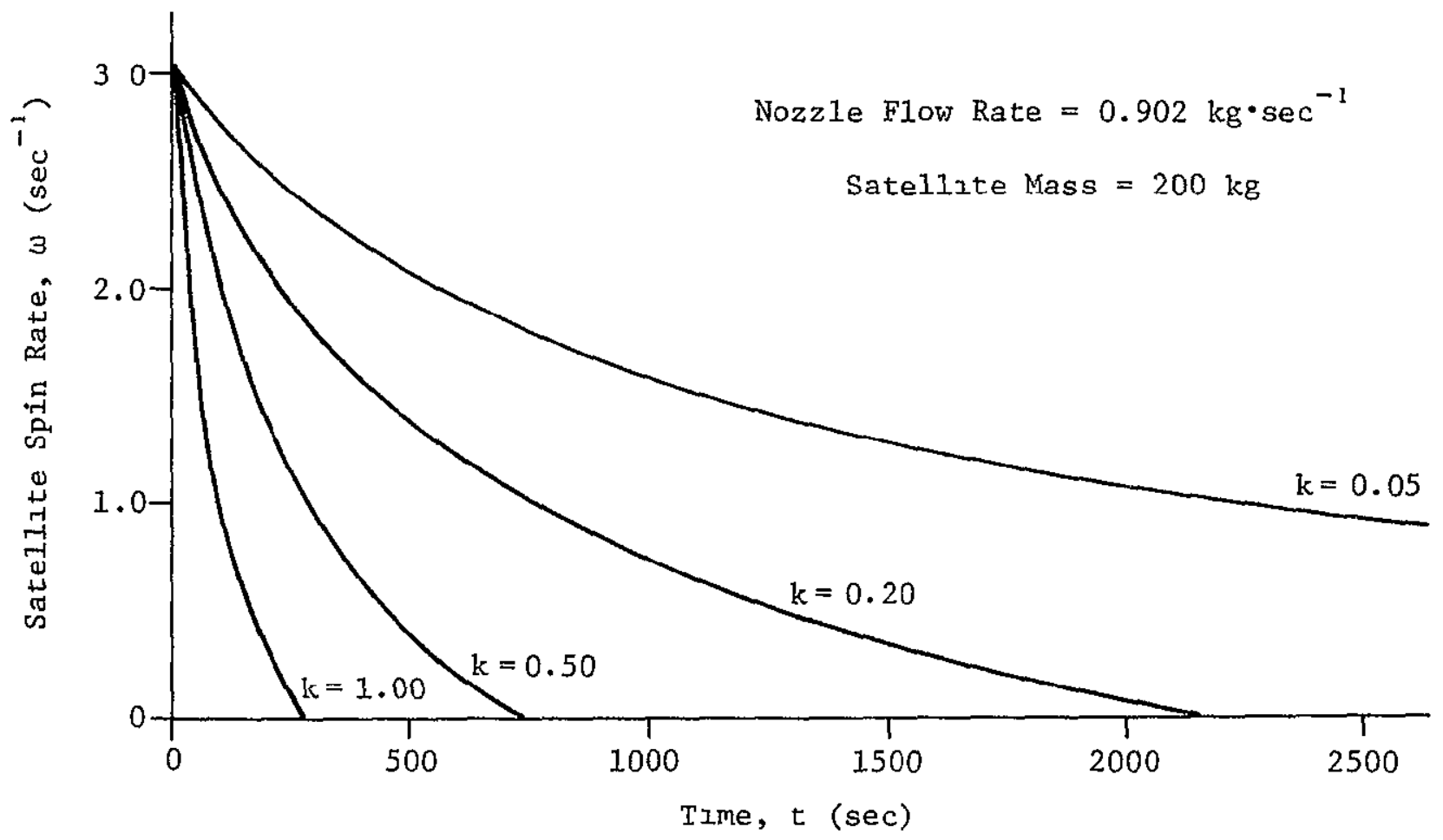

Figure 9 Typical Satellite Despan Profiles. 


\author{
CHAPTER V \\ EXAMPLE APPLICATION: OSO - 5 RETRIEVAL
}

As an example of a potentıal application of the WST, the retrıeval of a disabled satellıte was consıdered. Included in this example application were four areas of investigation: satellite selection, passivation, capture and stowage. For the satellute selected, despin tımes and total water mass requirements were computed. Conceptual designs of the spray, capture and stowage mechanism have also been included.

\title{
5.1 Satellite Selection
}

Prior to the selection of a satellate to be despun and retrieved, a selectıon criterıa was established. The particular satellite selected had to be:

1. A U.S. satellıte, preferably of NASA orıgın.

2. Compatible with size and mass limitations for shuttle payload.

3. Its orbit must be reachable by the shuttle.

Applyzng these criteria to a survey of satellites presently in orbit, a selection was made.

The shuttle retrieval envelope is Illustrated in Figure 10. Thls figure depicts a summary of shuttle orbit capabilities with respect to semimajor axıs, inclinatıon and delıverable payload. It also illustrates the effect of launch site and the use of orbital maneuverıng subsystem (OMS) kits on the attainable orbıts. Addıtional 


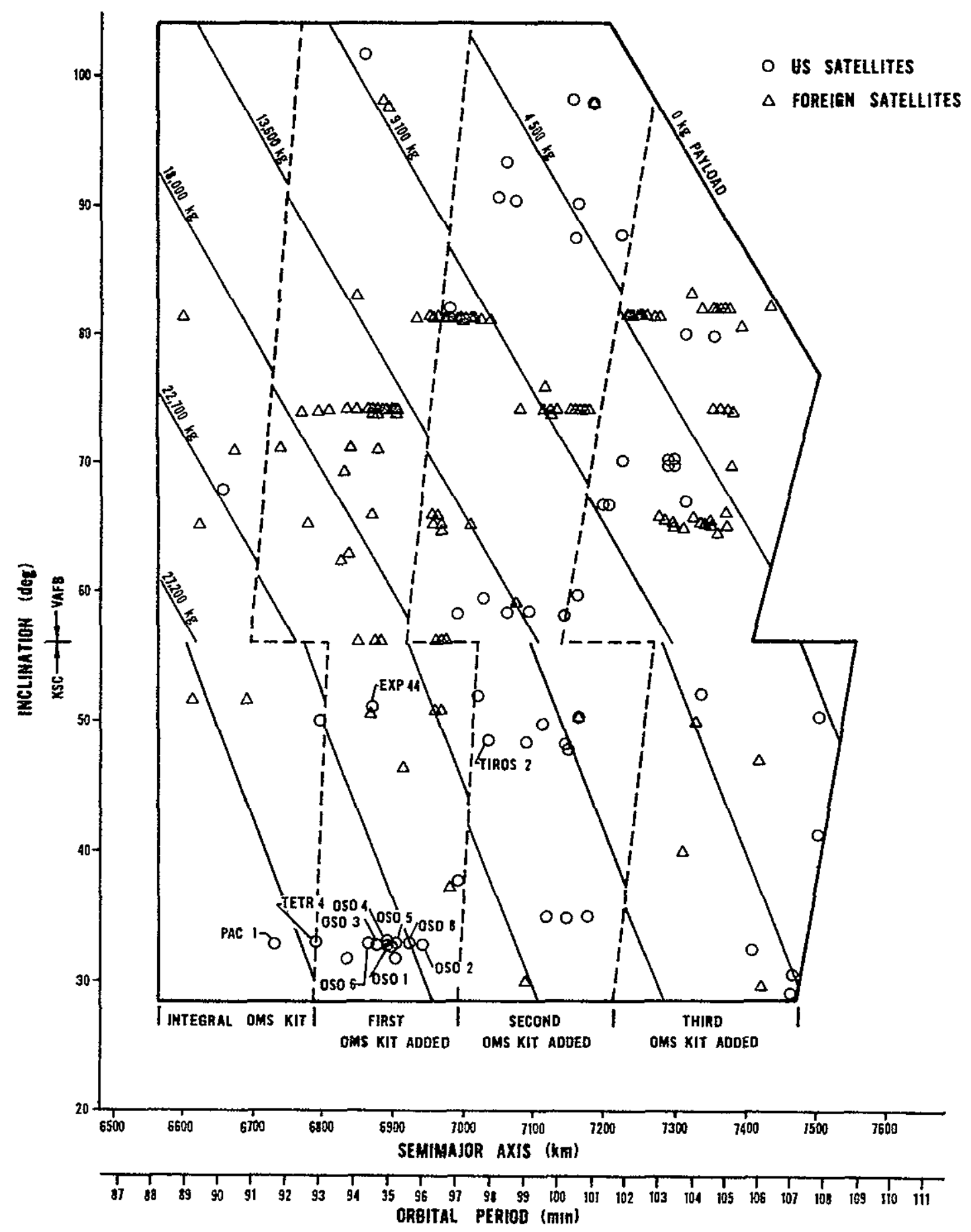

Fıgure 10. Shuttle Retrieval Envelope (10)(11). 
shuttle orbit and payload capabilitıes are presented in Appendix A. In addition to shuttle capabilities, Figure 10 shows a complete set of satellites which are reachable by the shuttle. These consist of spacecraft launched up to June 30, 1976 and Include U.S. and forelgn spacecraft. For a detalled listing of each indlvidual satelizte and Its orbıtal parameters, refer to Appendix B.

A final list of candidate satellutes was obtalned by elıminatıng those satellites within the shuttle retrieval envelope which are too large or massive to be retrieved. In addıtıon, only those satellites with Inclination between 32.0 and 57.0 degrees, $1 . e$. , within the proposed Inclination range for the first six shuttle orbital flight tests (12), were considered. Table IV lists the resulting candidate satellites; Figure 10 shows thelr positions. Of these, oso-5 Orbiting Solar Observatory, was selected on the rationale that it presents a fairly severe comblnation of the individual conditions which make retrıeval dıfficult weight, sıze and spın rate There are heavier, larger, or faster spınnıng candzdate satellites, but an example based on OSO- 5 wIIl be Illustrative of the problems assoclated with the middle range of each of these conditions.

The 0 SO- 5 is the fifth in a serıes of eight scientific satellites desıgned as a vehıcle for experiments which collect solar and celestıal navigatıon data. It was manufactured by Ball Brothers Research Corporation, Boulder, Colorado for NASA's Goddard Space Flight Center and launched on 22 January 1969 from Kennedy Space Center. It contaıns eıght prımary scientıfic Instruments furnıshed by U.S. government agencıes, and U.S., Brıtısh and French unıversıties It was successfully operated untıl 1974, when It was placed in a safe, 
Table IV

Candrdate Sate11ıtes for Despin and Retrieval

\begin{tabular}{|c|c|c|c|c|c|c|c|c|}
\hline Name & & $\begin{array}{l}\text { Launch } \\
\text { Date }\end{array}$ & $\begin{array}{l}\text { Semzmajor } \\
\text { Axis }(\mathrm{km})\end{array}$ & $\begin{array}{l}\text { Inclination } \\
\text { (deg) }\end{array}$ & $\begin{array}{l}\text { Mass } \\
(\mathrm{kg})\end{array}$ & $\begin{array}{l}\text { Diameter } \\
\text { (m) }\end{array}$ & $\begin{array}{l}\text { Wydth } \\
\text { (m) }\end{array}$ & $\begin{array}{c}\text { InItial Spin Rate } \\
\text { (rpm) }\end{array}$ \\
\hline Tiros & 2 & Nov 60 & 7038 & 48.5 & 126 & $--^{a}$ & $--^{a}$ & 10 \\
\hline oso & 1 & $\operatorname{Mar} 62$ & 6901 & 32.8 & 208 & 2.34 & 0.94 & 30 \\
\hline OSO & 2 & Feb 65 & 6939 & 32.8 & 247 & 2.34 & 0.94 & 30 \\
\hline oso & 3 & $\operatorname{Max} 67$ & 6890 & 32.8 & 284 & 2.57 & 0.79 & 30 \\
\hline oso & 4 & Oct 67 & 6897 & 32.9 & 271 & 2.57 & 094 & 30 \\
\hline oso & 5 & $\operatorname{Jan} 69$ & 6908 & 32.9 & 291 & 2.34 & 0.97 & $30-40$ \\
\hline oso & 6 & Aug 69 & 6865 & 32.9 & 290 & 2.34 & 0.94 & $30-40$ \\
\hline PAC & 1 & Aug 69 & 6736 & 32.9 & 120 & 1.35 & 488 & $--^{a}$ \\
\hline EXPLORER & 44 & Jul 71 & 6879 & 51.0 & 118 & 0.76 & 0.58 & 60 \\
\hline TETR & 4 & Sep 71 & 6795 & 33.0 & 20 & 0.30 & 0.30 & $--^{a}$ \\
\hline OSO & 8 & Jun 75 & 6924 & 32.9 & 1066 & 3.07 & 2.11 & 6 \\
\hline
\end{tabular}

a Data not avallable. 
stowed mode of operation.

The OSO - 5 has a diameter of $1.12 \mathrm{~m}$ and height of $0.97 \mathrm{~m}$, as shown In Figure 11. In the launch condıtion, the arms were folded alongside the third stage of the launch vehicle. Total launch weight was $291 \mathrm{~kg}$. Additıonal mass and inertıa propertıes are given in Table V.

The spacecraft consisted of two main structural sections: the rotating wheel, and the solar-orlented sall The wheel consists of nine wedge-shaped compartments arranged around the central hub and azimuth shaft assembly. Four of the compartments housed the wheel control electronics Attached to three compartments are the extendible arms supporting the spin control gas bottles and reaction jets. These arms are released from the stowed state durung the launch sequence and moved upward Into the plane of the wheel, thereby increasing its effective diameter and spın moment of inertıa. The wheel and sail are connected by the azımuth shaft assembly, whych Includes appropriate bearıngs and azimuth shaft, and allows the pointed instruments to be pointed toward the sun.

When operatıonal, the sall structure maintalned a fixed Inertial attztude and the wheel structure rotated at between 27 and $39.6 \mathrm{rpm}$. In its nonoperating mode, however, both parts rapidly equalize their rates due to bearıng friction. Calculations show that the current angular rate is approximately $25 \mathrm{rpm}$.

\subsection{Satelizte Passivation}

The elimination of oso-5 angular momentum was considered as an example application of the WST. Figure 12 Illustrates the 


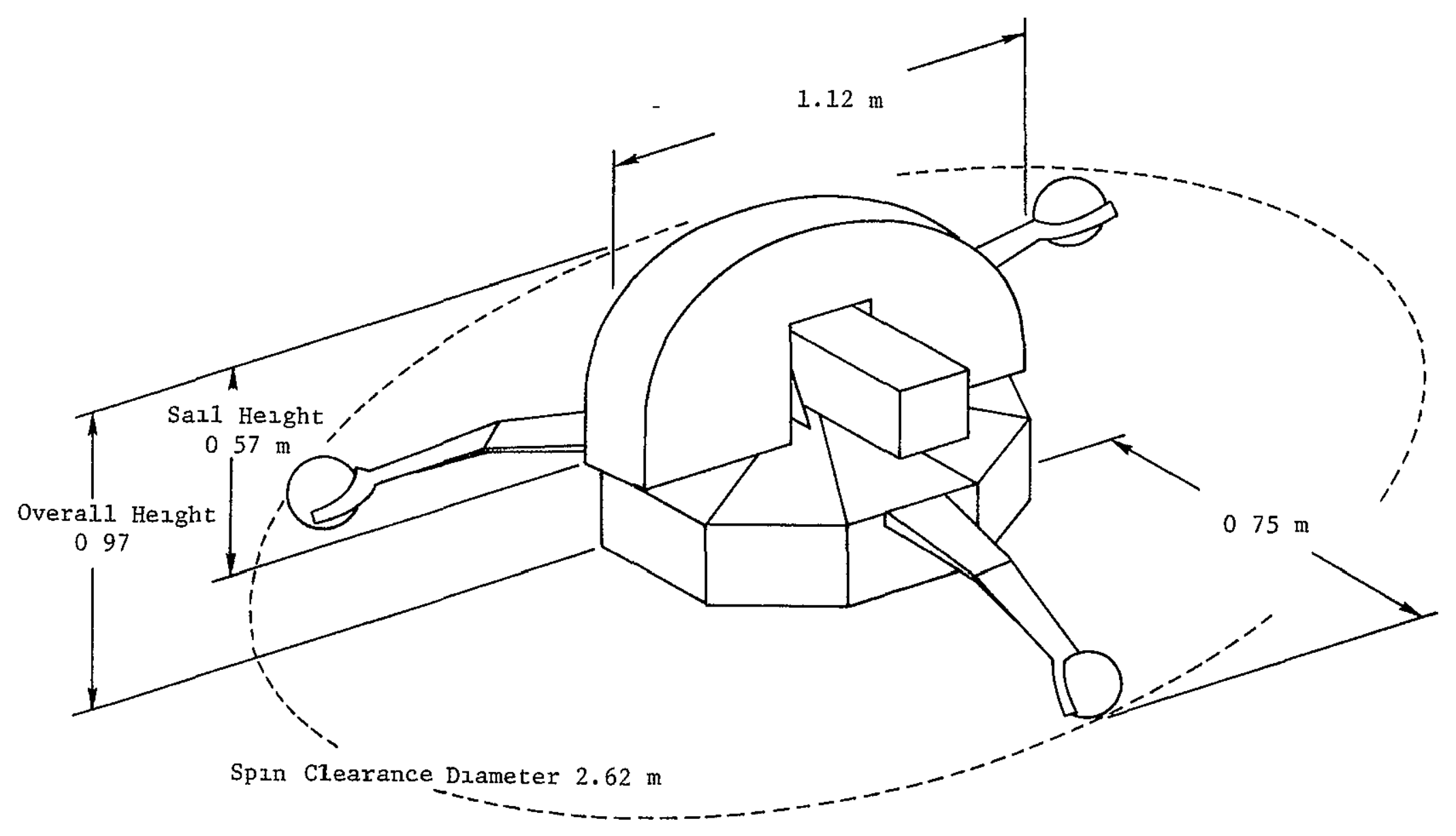

Figure 11. OSO- 5 Overa11 Dimensions (13) 
Table V

OSO - 5 Mass and Inertıa Properties

\begin{tabular}{|c|c|c|}
\hline Propertzes & \multicolumn{2}{|c|}{$\begin{array}{c}\text { Measured or } \\
\text { Calculated Values }\end{array}$} \\
\hline Launch Mass (kg) & & 291 \\
\hline $\begin{array}{l}\text { Spin Moment of } \\
\text { Inertza - Wheel } \\
\left(\mathrm{N} \cdot \mathrm{m} \cdot \mathrm{s}^{2}\right)\end{array}$ & 18.70 & $\begin{array}{l}\text { Arms Down } \\
\text { Arms Up }\end{array}$ \\
\hline $\begin{array}{l}\text { Spin Moment of } \\
\text { Inertza - Wheel } \\
\text { and SaI1 }\left(\mathrm{N} \cdot \mathrm{m} \cdot \mathrm{s}^{2}\right)\end{array}$ & 21.67 & $\begin{array}{l}\text { Arms Down } \\
\text { Arms Up }\end{array}$ \\
\hline $\begin{array}{l}\text { Average Transverse } \\
\text { Moment of Inertıa } \\
\left(\mathrm{N} \cdot \mathrm{m} \cdot \mathrm{s}^{2}\right)\end{array}$ & $\begin{array}{l}17.70 \\
18.13\end{array}$ & $\begin{array}{l}\text { Arms Down } \\
\text { Arms Up }\end{array}$ \\
\hline $\begin{array}{l}\text { Ratıo of Spın MOI } \\
\text { to Transverse MOI }\end{array}$ & 1.36 & Arms Up \\
\hline
\end{tabular}




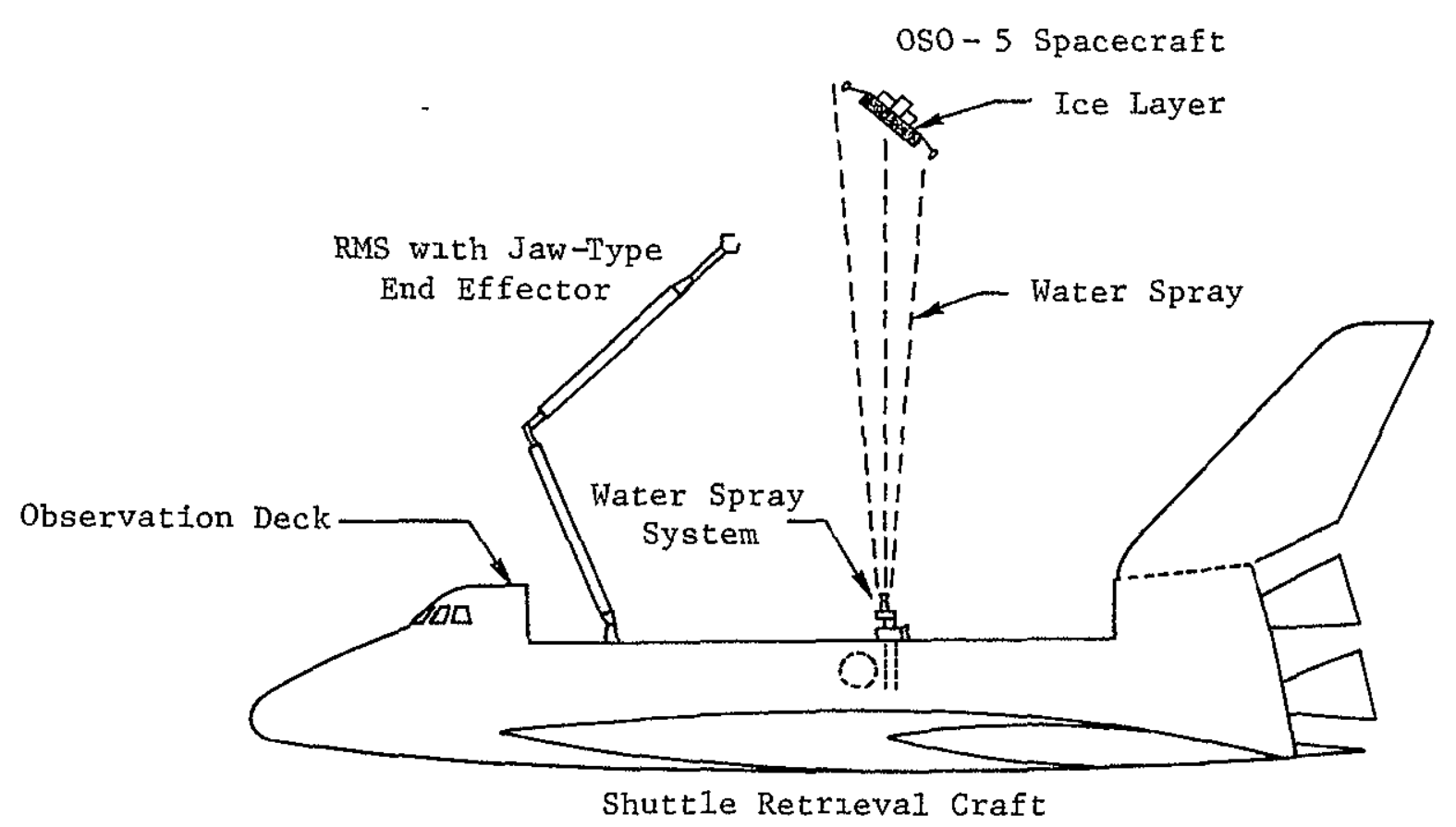

Figure 12. OSO-5 Retrieval Operation 
scheme used for this operation. Water is sprayed from the shuttle retrzeval craft, impıngıng upon 0so-5, quickly freezıng, formıng a thin layer of ice over portıons of z.ts surface. In this design the nozzle, water and assocrated hardware are located in the shuttle payload bay. One possible spray system is shown in Figure 13, mounted on an orbital flught test pallet. This system consusts of two spherıcal water storage tanks with $500 \mathrm{~kg}$ capacity each. The tanks are 1Ined whth flexıble rubber bladders. When pressurized by the small nitrogen tank, water is forced to the nozzle where it is then sprayed. The nozzle is pointed via controlled inputs from the shuttle observation deck, makıng an extravehicular actıvity (EVA) unnecessary. Low power heaters may be incorporated into the nozzle desıgn to prevent freezing and eventual blocking of the nozzle.

The equations of motion developed previously were used to simulate the despin of OSO-5 via the WST. Using the mass and Inertia properties Iıted in Table $V$, and assuming an initıal spin rate of $25 \mathrm{rpm}$, total water mass requirements and despin times were calculated. The results of these calculations are graphed in Figures 14 and 15 for varlous values of $k$. For a $k$ value of 0.50 , the total water mass necessary to eliminate $98 \%$ of the angular momentum 15 less than $700 \mathrm{~kg}$ The associated despin time is on the order of 700 seconds.

\subsection{Satellite Capture}

Havıng despun $0 S O-5$, the capture sequence begıns. As Illustrated in Figure 12, the actual capture of OSO-5 is performed using the remote manipulator system (RMS) with a Jaw-type end effector. Recieving controlled Inputs from the shuttle observation deck, the RMS 


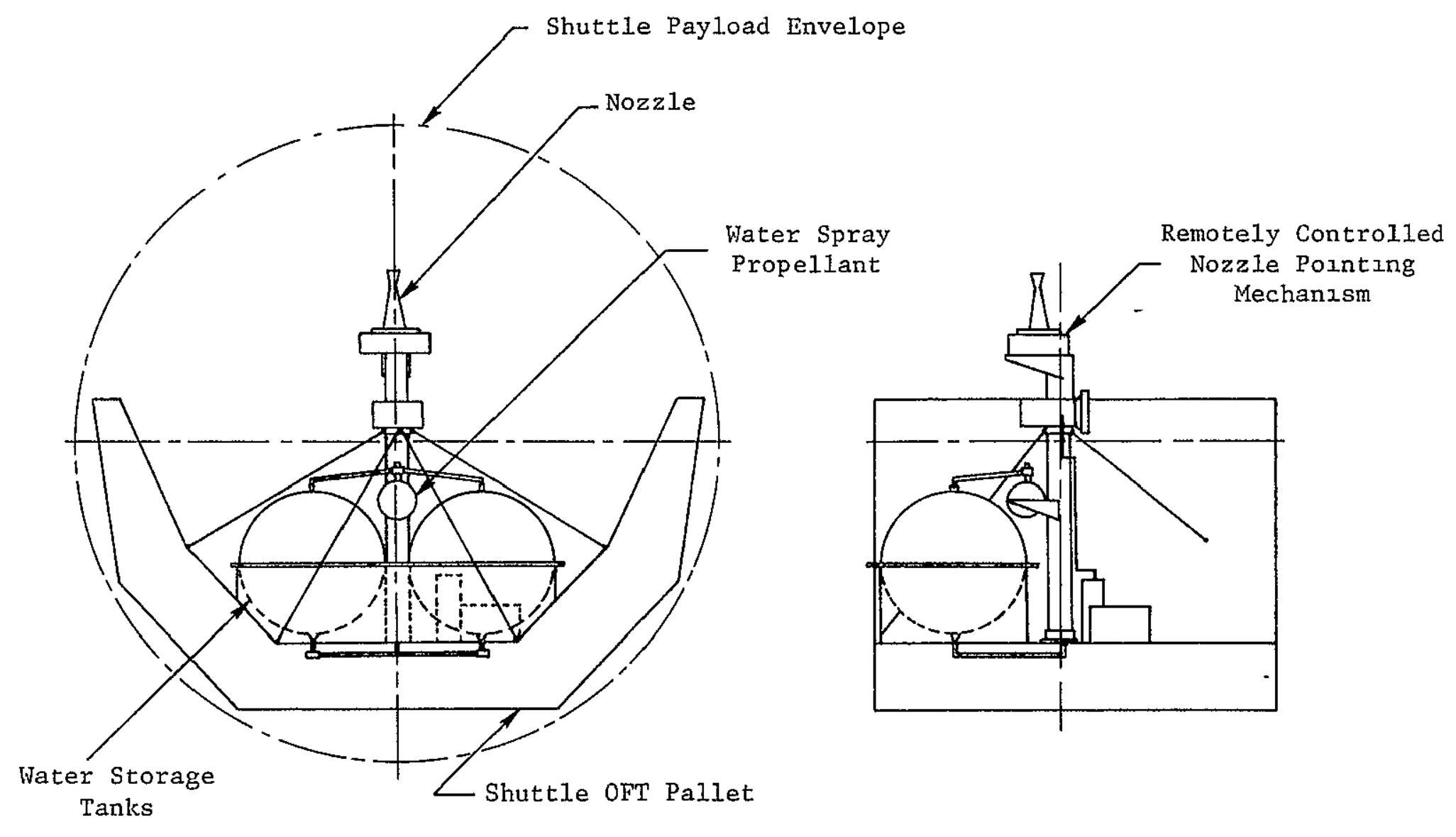

Figure 13 Pallet lounted Nater Spray System. 


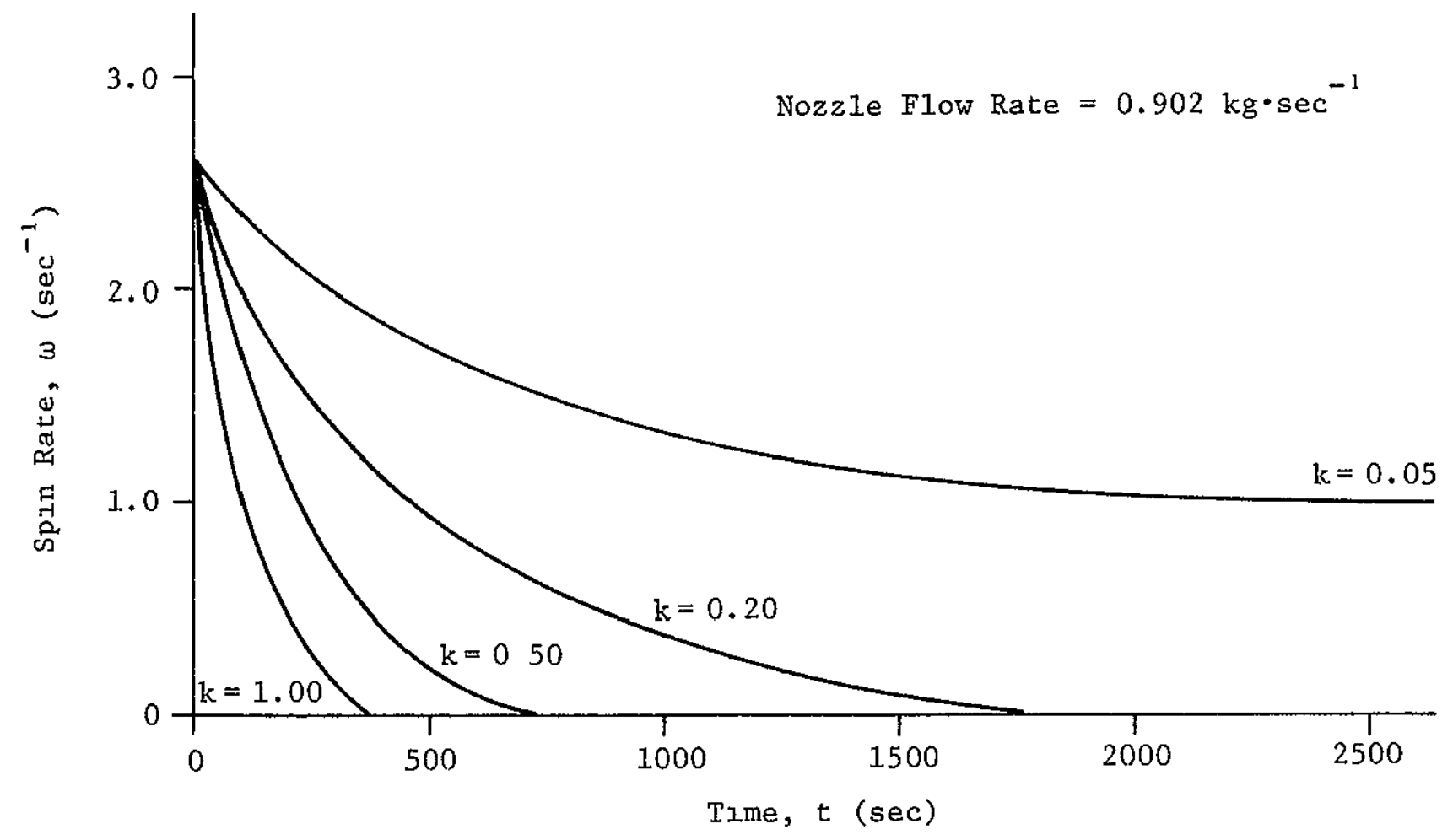

Figure 14. Typıcal Despin Profiles for the OSO-5 Spacecraft 


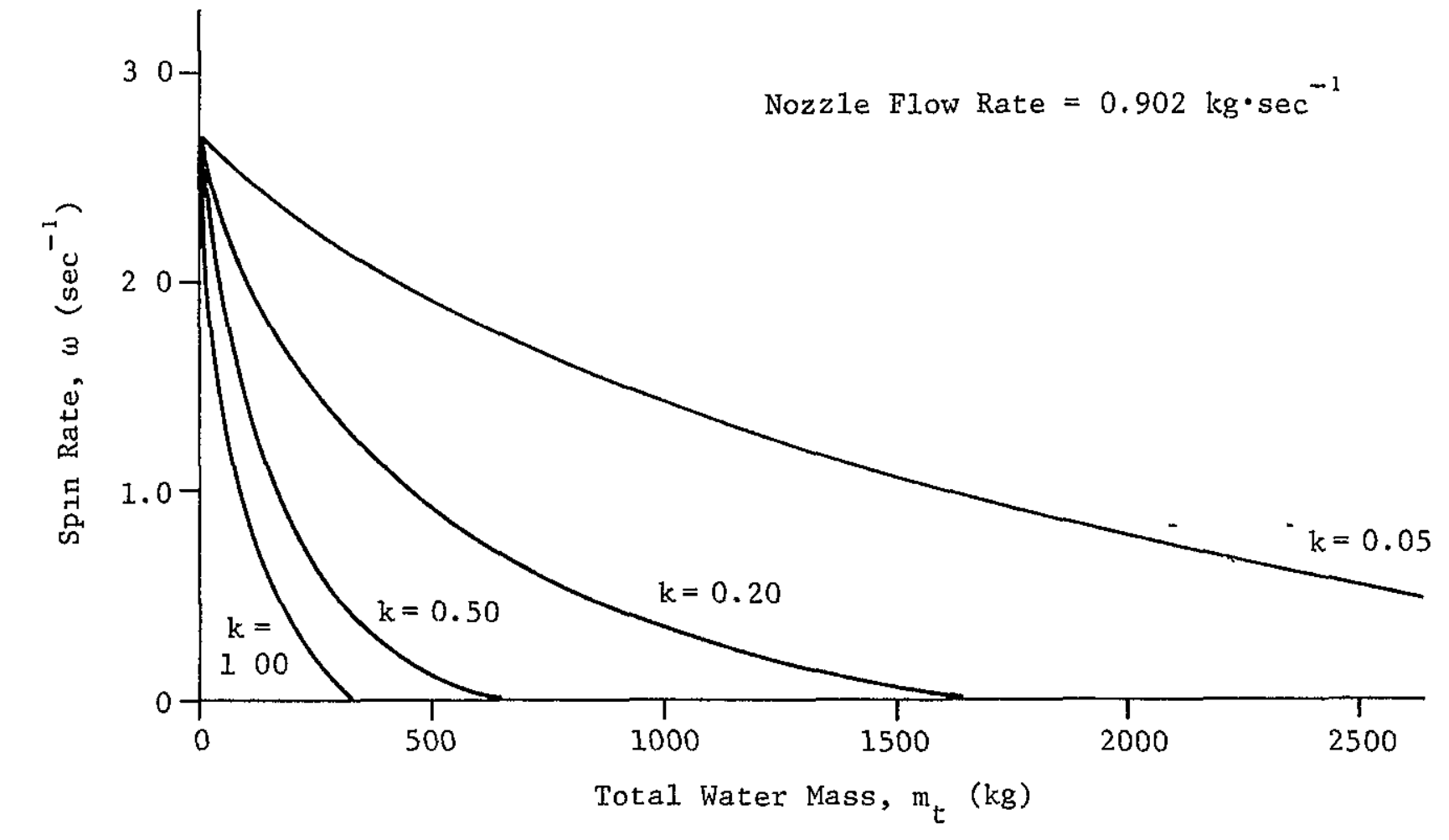

Figure 15 Total Water Mass Requirements for Despinning the oso- 5 Spacecraft 
moves the mechanical Jaws into positzon about one of the oso- 5 arms. The jaws close, capturing the spacecraft in its grip. The RMS then returns to the shuttle bay with the satellite for stowage and return.

\subsection{Satellite Stowage}

The stowage of 0 SO -5 in the shuttle bay is Illustrated in Figure 16. This scheme employs a specıally designed hydraulic grappler which holds the spacecraft securely in place through reentry and landing. The conceptual design of this grappling mechanism is Illustrated In Figure 17. In use, the RMS positions OSO- 5 such that its attachment fltting, I.e., the mount whlch orıginally attached the spacecraft to the Iaunch vehıcle, Is positioned within the hooks of the hydraulic grappler. Once in place, a signal is automatically fed back to the control logic which pressurızes the grappler mechanısm causing it to contract, locking tightly around the attachment fittzng. This stowage operation is controlled from the shuttle observation deck, makıng an EVA unnecessary. 


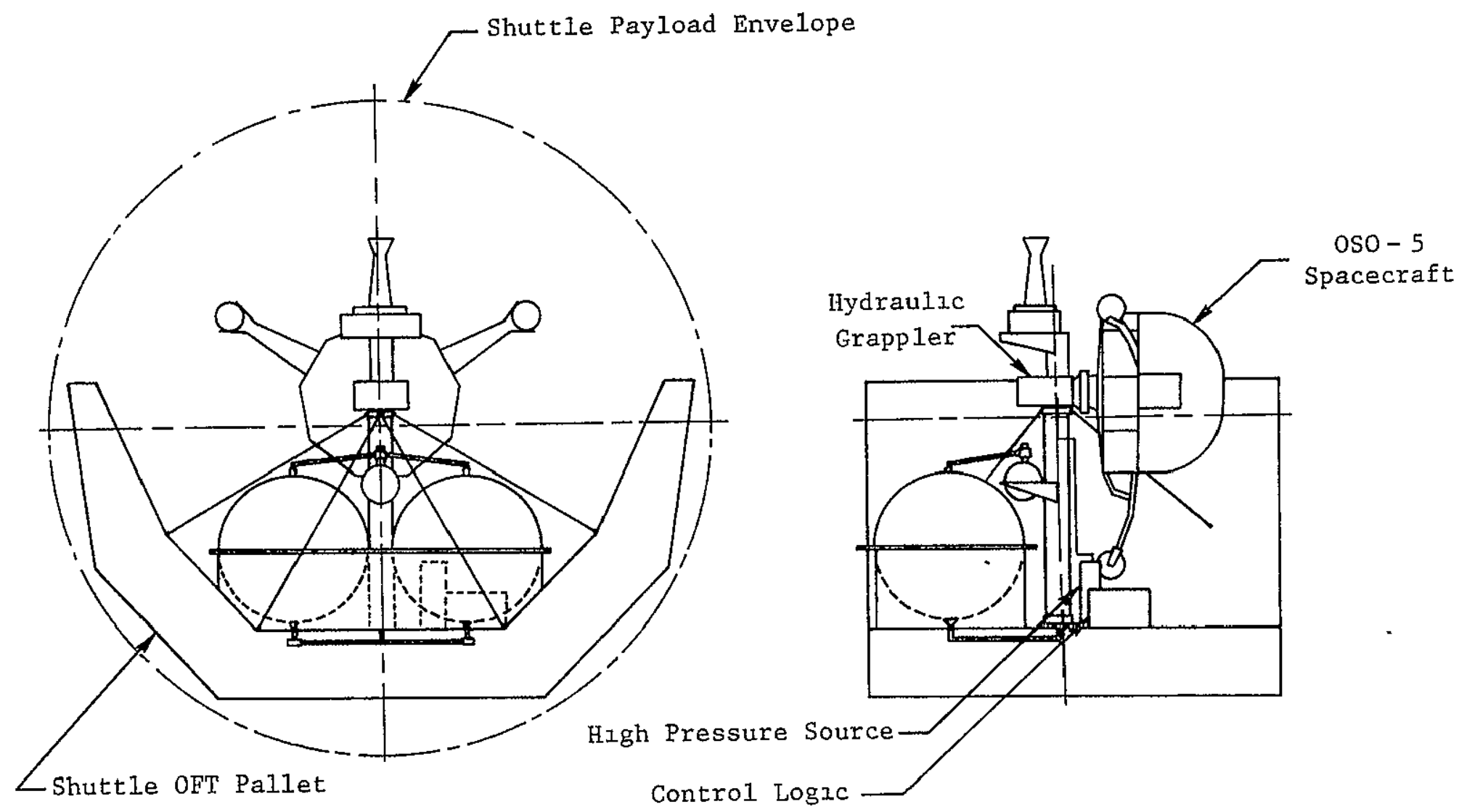



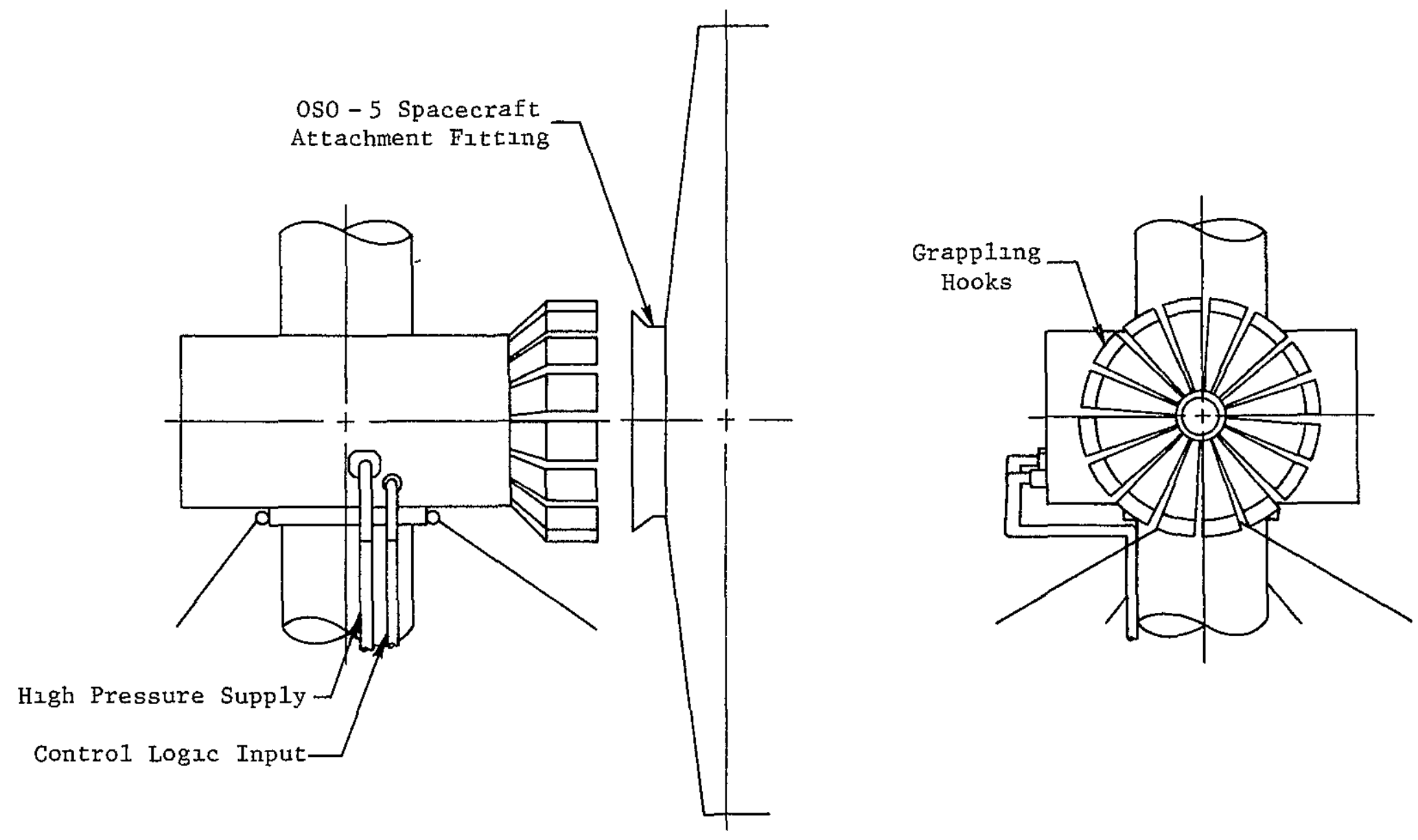

Figure 17 Hydraulic Grappling Mechanısm. 
CHAPTER VI

CONCLUSIONS

A new and safe technique for elimznating angular momentum of dusabled spacecraft has been presented here. This would appear to be an Ideal method of despınning because the required logic is extremely simple and there are no safety hazards involved. Furthermore, the working part of the system has essentially no cost and is expendable and need not be brought back to earth.

Experimental results have indicated that the accumulation and sublimation of Ices in a space-like environment is compatible with the total concept of the water spray retrieval operatzon. The results show that water freezes almost Immediately upon exhaustıng Into a vacuum, and sublimes slower than other ices tested. The effects of additives 1xke alcohol is to ancrease the sublimation rate which results in a faster retrieval operation. In addition, the proper concentration of alcohol in water can delay freezing of the mixture untzl at contacts the spinning vehıcle. Several factors were seen as effecting the sublimatıon rate: ıce layer thıckness, surface area, background pressure and temperature. The results also show that proper nozzle design must be consıdered to keep dispersion at a minzmum

Based on the assumptions and calculations made in this InvestIgation, It would appear that most old spacecraft in orbits reachable by the space shuttles can be retrieved If spinning, through the use of the WST. Durıng the operational application of this technique, it may be requared for the crew to wast up to two hours in order to actually capture the object. This is not seen as a major deterrent in Its 
application. Furthermore, the associated masses of water which must be carried into oxbit are relatıvely low compared to the maximum capability of the space shuttle.

Further testing and analyses are required before operatıonal use and Investments are made for development. These tests should Include actual orbital flıghts which are now under consideration. 


\section{REFERENCES}

1. Canettı, G.S., "Safety In Earth Orbit Study," Final Report, Rockwe11 Internationa1, SD 72-SA-0094, Vol. III, NASA Contract NAS9-12004, July 1972.

2. Canettı, G.S., "Recovery From a Tumbling Condıtion In Space," IAF Paper No. A-76-04, Presented at the 27th Congress of the I.A.F., Anahe1m, October 10-16, 1976.

3. Kaplan, M.H., "Despınnıng and Detumblıng Sate11ıtes in Rescue Operations," Proceedings of the Fifth International Space Rescue Symposıum, International Academy of Astronautics, May 1973, pp. 225-243.

4. Kaplan, M.H., "Technical Problems Related to Orbıtal Capture of Passive Objects," Thırd Semı-Annual Progress Report Under NASA Grant NSG-7078, The Pennsylvanıa State Unzversity, 1975.

5. Kaplan, M.H. and Freesland, D.C., "Use of Water Sprays in Space Rescue and Retrieval Operations," IAF Paper No. A-76-09, presented at the 27th Congress of the I.A.F., Anahe1m, October 10-16, 1976.

6. Watson, Murray and Brown, "The Stabilıty of Volatıles in the Solar Sys tem," Icarus 1, pp. 317-327.

7. Sharma, R.D. and Buffalano, C., "Temperature and Size Historıes of Liquid $\mathrm{H}_{2}, \mathrm{O}_{2}$, and $\mathrm{H}_{2} \mathrm{O}$ Particles Released In Space," Journal of Geophysıcal Research, Vo1. 76, No. 1, January 1971, pp. 232237 .

8. Grubın, C., "Mechanıcs of Varıable Mass Systems," Franklın Institute Journa1, Vo1. 276, October 1963, pp. 305-312.

9. Kaplan, M.H., Modern Spacecraft Dynamıcs and Contro1, John WIley and Sons, New York, 1976, Chapter 2.

10. "Space Shuttle Systems Payload Accomodatzons," NASA Johnson Space Center, JSC-07700, Vo1. XIV, December 1976, Chapter 3

11. "Sate11ıte SItuatıon Report," NASA Goddard Space Flıght Center, Vol. 16, No. 3, June 1976.

12. "Announcement of Opportunity for Space Shuttle Orbital Flight Test Program," NASA A.0. No. OPPI-76-1, September 1976, p. 4.

13. "OSO- 5 Orbiting Solar Observatory," Final Report Prepared Under NASA Contract NAS5-9300, Bal1 Brothers Research Corporation, AprI1 1971. 
APPENDIX A

SPACE SHUTTLE PAYLOAD CAPABILITY

The space shuttle payload delivery capabilities are outlined In the following figures. Figures 18 and $19 \mathrm{graph}$ payload mass as a function of circular orbital altıtude for Kennedy Space Center (KSC) and Vandenberg Alr Force Base (VAFB) launches respectively. The addition of orbıtal maneuvering subsystems (OMS) kits is also shown. Figure 20 graphs payload mass versus orbit inclination. Again, the effects of additional OMS knts are included. For the purpose of constructung these figures, both delıvery and rendezvous maneuvers have been included in computing payload masses. 


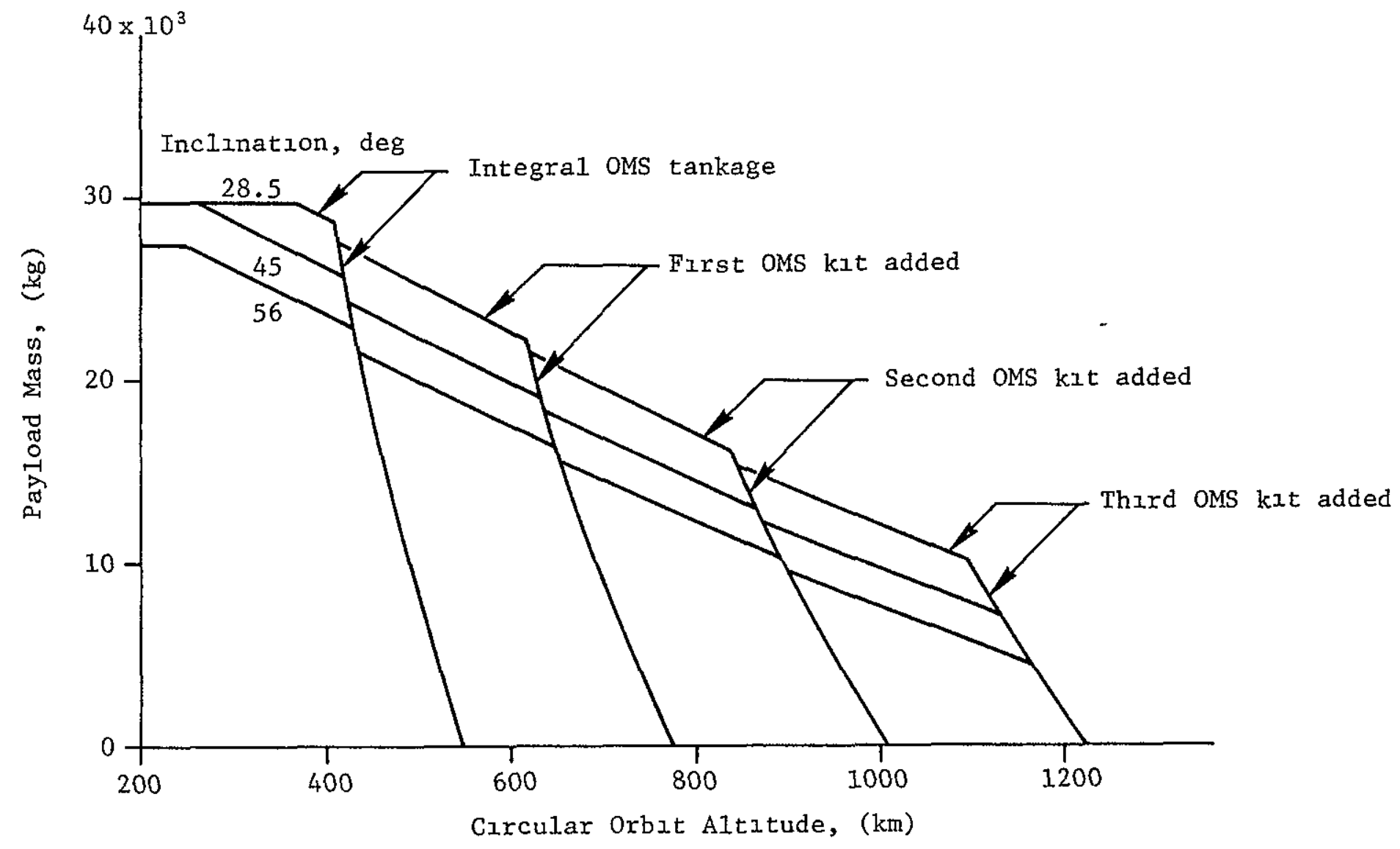

Figure 18 Payload Mass Versus Cıxcular Orbıtal Altıtude - KSC Launch, Delivery and Rendezvous (10) 


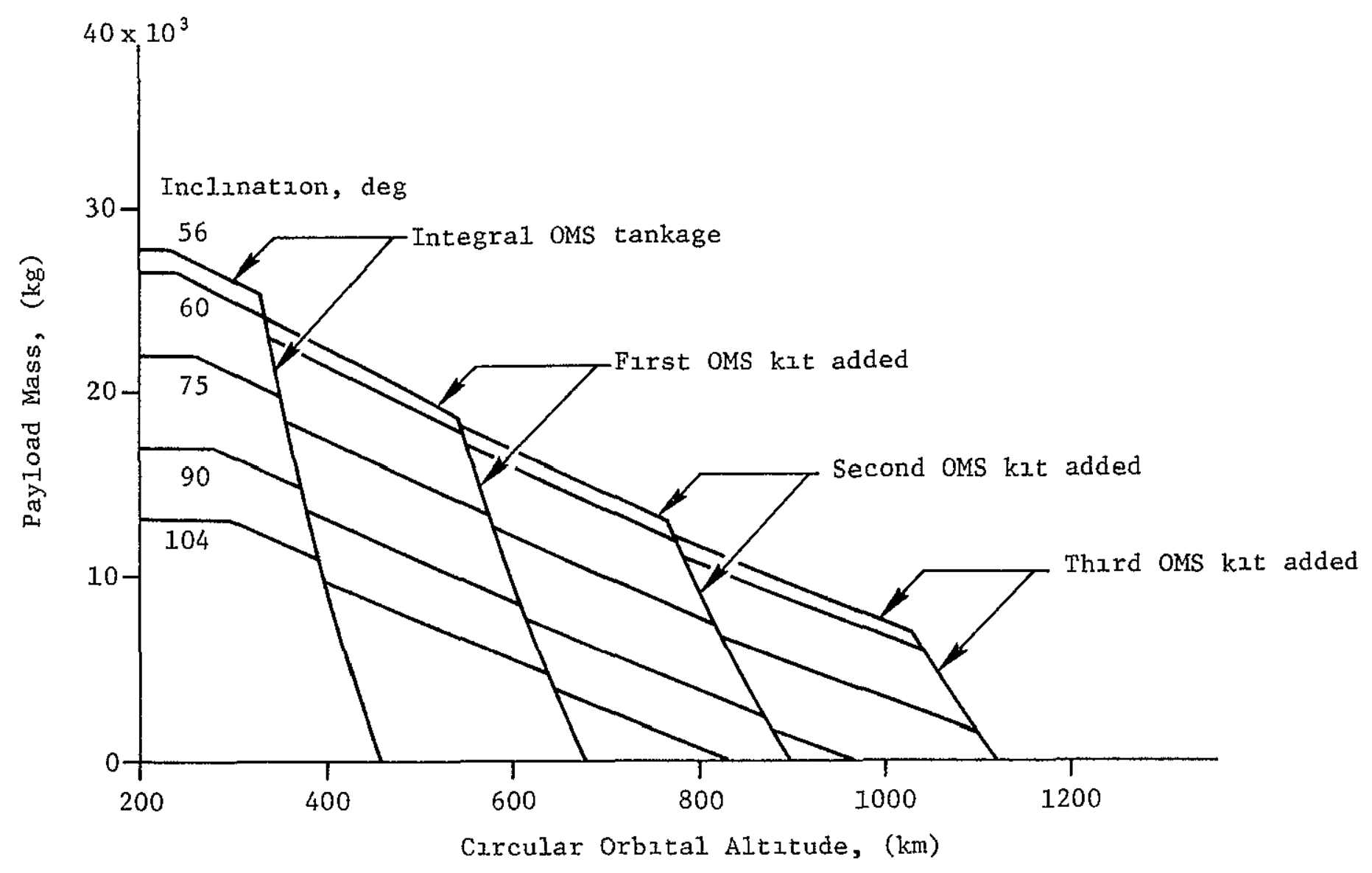

Figure 19 Payload Mass Versus Circular Orbıtal Altıtude-VAFB Launch, Delıvery and Rendezvous (10). 


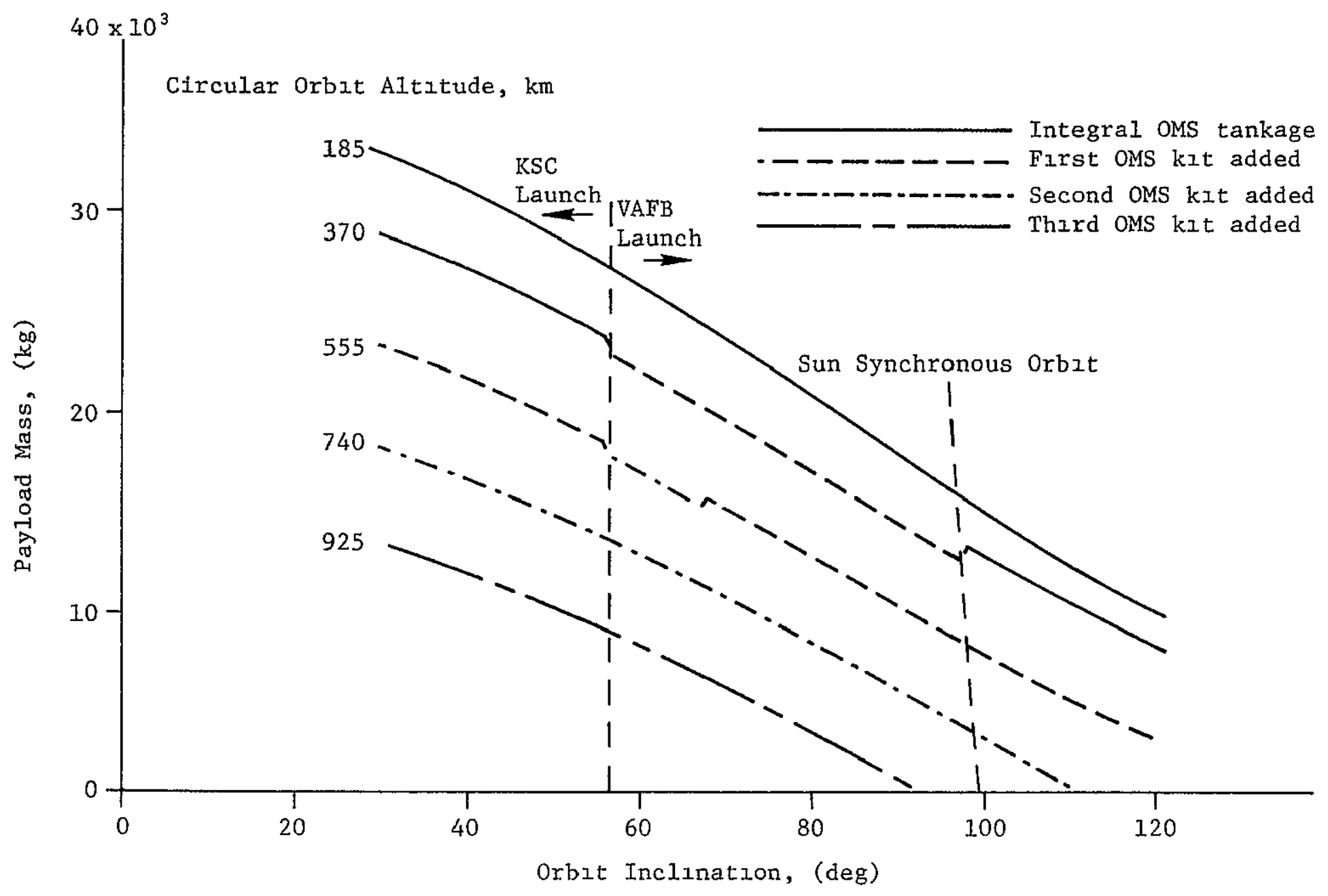

Figure 20. Payload Mass Versus Inclination for Varıous Circular Orbital Altitude, Delivery and Rendezvous (10). 


\section{APPENDTX B}

SATELLITES WITHIN THE SHUTTLE RETRIEVAL ENVELOPE

Orbital data is tabulated for those satellites withın the shuttle retrıeval envelope given in Figure 10. Table VI includes U.S. satellites while Table VII includes forelgn satellites Satellite name, international designation, perıod and Inclination are listed. These tables have been constructed from data compiled by NASA (11). 
Table VI

U.S. Satellites Withın the Shuttle Retrieval Envelope (11)

\begin{tabular}{|c|c|c|c|}
\hline Name & $\begin{array}{l}\text { International } \\
\text { Designation }\end{array}$ & $\begin{array}{l}\text { Perıod } \\
(\min )\end{array}$ & $\begin{array}{l}\text { Inclination } \\
\text { (deg) }\end{array}$ \\
\hline Explorer 7 & 1959 IOTA 1 & 100.6 & 50.3 \\
\hline Tiros 1 & 1960 BETA 2 & 99.0 & 48.3 \\
\hline Transit 2A & 1960 ETA 1 & 101.4 & 66.6 \\
\hline GREB & 1960 ETA 2 & 101.3 & 66.6 \\
\hline Tiros 2 & 1960 & 97.9 & 48.5 \\
\hline Explorer 11 & 1961 & 107.1 & 28.8 \\
\hline Transzt 4A & 1961 OMICRON 1 & 103.7 & 66.8 \\
\hline INJUN SR3 & 1961 OMICRON 2 & 103.7 & 66.8 \\
\hline Tiros 3 & 1961 RHO 1 & 100.3 & 47.8 \\
\hline Transit $4 \mathrm{~B}$ & 1961 A ETA 1 & 105.7 & 32.4 \\
\hline TRAAC & 1961 A ETA 2 & 105.7 & 32.4 \\
\hline Tiros 4 & 1962 BETA 1 & 100.2 & 48.2 \\
\hline oso 1 & 1962 ZETA 1 & 95.1 & 328 \\
\hline Turos 5 & 1962 A ALPHA 1 & 100.2 & 58.0 \\
\hline Tiros 6 & 1962 A PSI 1 & 98.5 & 58.3 \\
\hline ANNA IB & 1962 B MU 1 & 107.8 & 50.1 \\
\hline Explorer 16 & 1962 B CHI 1 & 104.3 & 52.0 \\
\hline Transit 5A & 1962 B PSI 1 & 98.3 & 90.6 \\
\hline Truos 7 & $63024 \mathrm{~A}$ & 97.0 & 58.2 \\
\hline $\begin{array}{l}\text { Research Satellzte } \\
\text { for Geophysics }\end{array}$ & $63026 \mathrm{~A}$ & 99.5 & 49.7 \\
\hline Centaur 2 & $63047 \mathrm{~A}$ & 107.0 & 30.3 \\
\hline Tiros 8 & $63054 \mathrm{~A}$ & 99.2 & 584 \\
\hline
\end{tabular}


Table VI (continued)

U.S. Satellites Within the Shuttle Retrueval Envelope (1I)

\begin{tabular}{|c|c|c|c|}
\hline Name & $\begin{array}{c}\text { International } \\
\text { Designation }\end{array}$ & $\begin{array}{l}\text { Period } \\
\text { (min) }\end{array}$ & $\begin{array}{l}\text { Inclination } \\
\text { (deg) }\end{array}$ \\
\hline Gravity Gradient & $64001 \mathrm{~B}$ & 103.3 & 69.9 \\
\hline EGRS & $64001 \mathrm{C}$ & 103.4 & 69.8 \\
\hline Solarad & $64001 \mathrm{D}$ & 103.4 & 69.9 \\
\hline Explorer 20 & $64051 \mathrm{~A}$ & 103.8 & 79.8 \\
\hline Explorer 22 & $64064 \mathrm{~A}$ & 104.6 & 79.6 \\
\hline Explorer 23 & $64074 \mathrm{~A}$ & 97.6 & 51.9 \\
\hline oso 2 & $65007 \mathrm{~A}$ & 95.9 & 32.8 \\
\hline Pegasus 1 & $65009 \mathrm{~A}$ & 93.8 & 31. 7 \\
\hline GREB & $65016 \mathrm{~A}$ & 103.4 & 70.0 \\
\hline Gravıty Gradıent & $65016 \mathrm{~B}$ & 103.4 & 700 \\
\hline Gravıty Gradient & $65016 \mathrm{C}$ & 103.4 & 70.0 \\
\hline Solarad & $65016 \mathrm{D}$ & 103.4 & 70.0 \\
\hline EGRS 3 & $65016 \mathrm{E}$ & 103.4 & 70.0 \\
\hline Oscar 3 & $65016 \mathrm{~F}$ & 103.3 & 70.0 \\
\hline Surcal & $65016 G$ & 101.9 & 70.0 \\
\hline Dodechedron & $65016 \mathrm{H}$ & 103.4 & 70.0 \\
\hline Explorer 27 & $65032 \mathrm{~A}$ & 107.8 & 41.1 \\
\hline Pegasus 2 & $65039 \mathrm{~A}$ & 95.2 & 31.7 \\
\hline Taros 10 & $65051 \mathrm{~A}$ & 100.5 & 98.1 \\
\hline OGO 2 & $65081 \mathrm{~A}$ & 100.5 & 87.3 \\
\hline Exp1orer 30 & $65093 \mathrm{~A}$ & 100.6 & 59.7 \\
\hline ESSA 1 & $66008 \mathrm{~A}$ & 101.1 & 97.8 \\
\hline OAO 1 & $66031 \mathrm{~A}$ & 100.8 & 35.0 \\
\hline
\end{tabular}


Table VI (contınued)

U.S. Sateliltes Within the Shuttle Retrieval Envelope (11)

\begin{tabular}{|c|c|c|c|}
\hline Name & $\begin{array}{l}\text { International } \\
\text { Designation }\end{array}$ & $\begin{array}{c}\text { Period } \\
(\min )\end{array}$ & $\begin{array}{l}\text { Inclination } \\
\text { (deg) }\end{array}$ \\
\hline OV1-10 & 66111 B & 98.5 & 93.4 \\
\hline oso 3 & $67020 \mathrm{~A}$ & 94.8 & 32.8 \\
\hline Gravity Gradzent 4 & $67053 \mathrm{C}$ & 103.3 & 69.9 \\
\hline Gravıty Gradıent 5 & $67053 \mathrm{D}$ & 103.3 & 699 \\
\hline ov1-12 & $67072 \mathrm{D}$ & 94.4 & 101.6 \\
\hline oso 4 & $67100 \mathrm{~A}$ & 95.0 & 32.9 \\
\hline Explorer 37 & $68017 \mathrm{~A}$ & 97.8 & 59.3 \\
\hline TETR 2 & $68100 \mathrm{~B}$ & 95.0 & 32.8 \\
\hline $\mathrm{OAO}-\mathrm{A} 2$ & $68110 \mathrm{~A}$ & 100.2 & 34.9 \\
\hline oso 5 & $69006 \mathrm{~A}$ & 95.2 & 32.9 \\
\hline OGO 6 & 69051. A & 96.8 & 81.9 \\
\hline oso 6 & $69068 \mathrm{~A}$ & 94.4 & 32.9 \\
\hline PAC 1 & $69068 \mathrm{~B}$ & 91.7 & 32.9 \\
\hline Explorer 44 & $71058 \mathrm{~A}$ & 94.6 & 51.0 \\
\hline OVI-2I & $71067 \mathrm{~B}$ & 100.9 & 87.6 \\
\hline TETR 4 & $71083 \mathrm{~B}$ & 92.9 & 33.0 \\
\hline Explorer 46 & $72061 \mathrm{~A}$ & 97.1 & 37.6 \\
\hline Copernzcus & 72065 A & 99.6 & 35.0 \\
\hline Trıac OI-IX & $72069 \mathrm{~A}$ & 100.6 & 90.0 \\
\hline Skylab 1 . & $73027 \mathrm{~A}$ & 93.0 & 50.0 \\
\hline Explorer 51 & $73101 \mathrm{~A}$ & 90.2 & 67.9 \\
\hline OSO 8 & $75057 \mathrm{~A}$ & 956 & 32.9 \\
\hline TIP 2 & $75099 \mathrm{~A}$ & 98.8 & 90.3 \\
\hline
\end{tabular}


Table VII

Forelgn Sateliztes Within the Shuttle Retxieval Envelope (II)

\begin{tabular}{|c|c|c|c|}
\hline Name & $\begin{array}{c}\text { International } \\
\text { Designation }\end{array}$ & $\begin{array}{l}\text { Period } \\
\text { (min) }\end{array}$ & $\begin{array}{l}\text { Inclination } \\
\text { (deg) }\end{array}$ \\
\hline Alouette 1 & 1962 B ALPHA 1 & 105.4 & 80.4 \\
\hline Polyot 1 & $63043 \mathrm{~A}$ & 98.7 & 58.8 \\
\hline Cosmos 58 & $65014 \mathrm{~A}$ & 96.3 & 65.0 \\
\hline Cosmos 72 & $65053 \mathrm{~B}$ & 94.1 & 56.0 \\
\hline Cosmos 74 & $65053 \mathrm{D}$ & 94.6 & 56.0 \\
\hline Cosmos 75 & $65053 \mathrm{E}$ & 94.7 & 56.0 \\
\hline FR-1 & $65101 \mathrm{~A}$ & 99.7 & 75.8 \\
\hline Cosmos 100 & $65106 \mathrm{~A}$ & 97.3 & 65.0 \\
\hline Cosmos 103 & $65112 \mathrm{~A}$ & 96.4 & 56.0 \\
\hline Cosmos 108 & $66038 \mathrm{~A}$ & 96.5 & 65.0 \\
\hline Cosmos 122 & $66057 \mathrm{~A}$ & 96.5 & 64.9 \\
\hline Drademe 1 & $67011 \mathrm{~A}$ & 103.7 & 39.9 \\
\hline Cosmos 144 & $67018 \mathrm{~A}$ & 96.1 & 81.1 \\
\hline Cosmos 151 & $67027 \mathrm{~A}$ & 96.7 & 56.0 \\
\hline Cosmos 156 & $67039 \mathrm{~A}$ & 96.4 & 81.1 \\
\hline Cosmos 158 & $67045 \mathrm{~A}$ & 100.4 & 74.0 \\
\hline Cosmos 184 & $67102 \mathrm{~A}$ & 96.6 & 81.1 \\
\hline Cosmos 189 & $67108 \mathrm{~A}$ & 93.0 & 73.9 \\
\hline Cosmos 192 & $67116 \mathrm{~A}$ & 99.7 & 74.0 \\
\hline Cosmos 198 & $67127 \mathrm{~A}$ & 103.4 & 65.1 \\
\hline Cosmos 206 & $68019 \mathrm{~A}$ & 96.5 & 81.2 \\
\hline Cosmos 209 & $68023 \mathrm{~A}$ & 103.1 & 65.3 \\
\hline Cosmos 220 & $68040 \mathrm{~A}$ & 98.9 & 740 \\
\hline
\end{tabular}


TableVII (continued)

Forelgn Satellites Within the Shuttle Retrıeval Envelope (11)

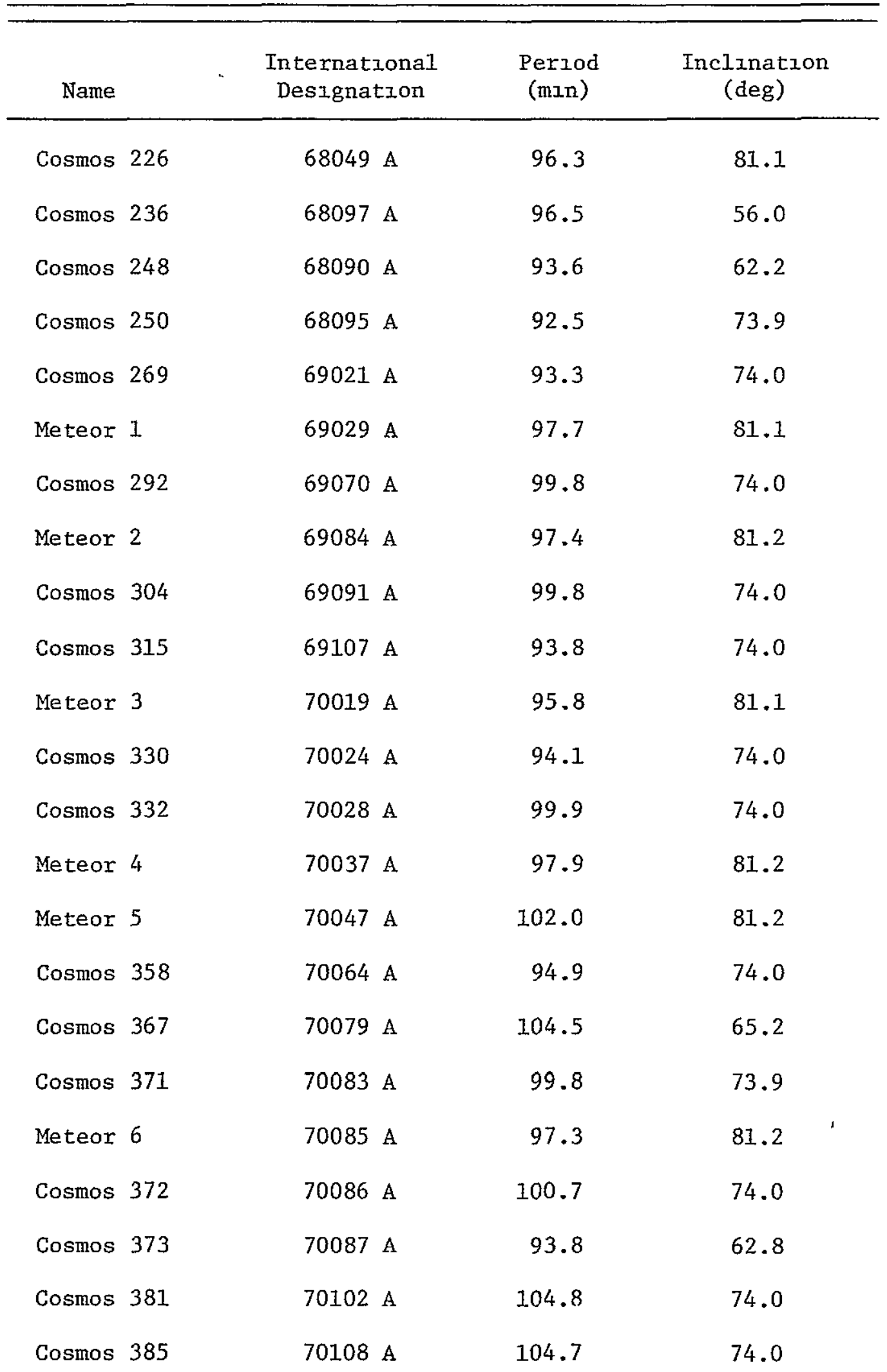


Table VII (contınued)

Forelgn Sateliltes Withın the Shuttle Retrieval Envelope (11)

\begin{tabular}{|c|c|c|c|}
\hline Name & $\begin{array}{l}\text { International } \\
\text { Designation }\end{array}$ & $\begin{array}{l}\text { Period } \\
\text { (min) }\end{array}$ & $\begin{array}{l}\text { Inclination } \\
\text { (deg) }\end{array}$ \\
\hline Cosmos 387 & $70111 \mathrm{~A}$ & 94.6 & 73.9 \\
\hline Cosmos 389 & $70113 \mathrm{~A}$ & 97.9 & 81.1 \\
\hline Meteor 7 & $71003 \mathrm{~A}$ & 97.4 & 81.2 \\
\hline Cosmos 394 & $71010 \mathrm{~A}$ & 96.4 & 65.8 \\
\hline Tansez & $71011 \mathrm{~A}$ & 106.0 & 29.6 \\
\hline Cosmos 395 & $71013 \mathrm{~A}$ & 94.8 & 74.0 \\
\hline Cosmos 400 & $71020 \mathrm{~A}$ & 104.9 & 65.8 \\
\hline Cosmos 402 & $71025 \mathrm{~A}$ & 104.9 & 64.9 \\
\hline Tournesol & $71030 \mathrm{~A}$ & 95.4 & 46.3 \\
\hline Meteor 8 & $71031 \mathrm{~A}$ & 96.9 & 81.2 \\
\hline Cosmos 407 & $71035 \mathrm{~A}$ & 100.9 & 74.0 \\
\hline Cosmos 422 & $71046 \mathrm{~A}$ & 105.0 & 74.0 \\
\hline Cosmos 425 & $71050 \mathrm{~A}$ & 94.6 & 74.0 \\
\hline Meteor 9 & $71059 \mathrm{~A}$ & 97.1 & 81.1 \\
\hline EOLE 1 & $71071 \mathrm{~A}$ & 100.6 & 50.1 \\
\hline Cosmos 436 & $71074 \mathrm{~A}$ & 94.6 & 740 \\
\hline Cosmos 437 & $71075 \mathrm{~A}$ & 94.8 & 74.0 \\
\hline Prespero & $71093 \mathrm{~A}$ & 106.3 & 82.0 \\
\hline Cosmos 460 & $71103 \mathrm{~A}$ & 94.7 & 73.9 \\
\hline Cosmos 461 & $71105 \mathrm{~A}$ & 93.7 & 69.2 \\
\hline Arzel 4 & 71109 A & 94.1 & 82.9 \\
\hline Cosmos 465 & $71111 \mathrm{~A}$ & 104.8 & 74.0 \\
\hline Cosmos 468 & $71114 \mathrm{~A}$ & 100.7 & 74.0 \\
\hline
\end{tabular}


TableVII (continued)

Forelgn Satellıtes Withın the Shuttle Retrieval Envelope (11)

\begin{tabular}{|c|c|c|c|}
\hline Name & $\begin{array}{l}\text { International } \\
\text { Designation }\end{array}$ & $\begin{array}{l}\text { Period } \\
\text { (min) }\end{array}$ & $\begin{array}{l}\text { Inclination } \\
\text { (deg) }\end{array}$ \\
\hline Cosmos 469 & $71117 \mathrm{~A}$ & 104.7 & 644 \\
\hline Meteor 10 & $71120 \mathrm{~A}$ & 102.6 & 81.2 \\
\hline Cosmos 475 & $72009 \mathrm{~A}$ & 104.7 & 74.0 \\
\hline Cosmos 476 & $72011 \mathrm{~A}$ & 97.1 & 81.2 \\
\hline$T D-1 A$ & $72014 \mathrm{~A}$ & 95.0 & 97.5 \\
\hline Cosmos 479 & $72017 \mathrm{~A}$ & 94.7 & 74.0 \\
\hline Meteor 11 & $72022 \mathrm{~A}$ & 102.5 & 81.2 \\
\hline Cosmos 489 & $72035 \mathrm{~A}$ & 104.7 & 74.0 \\
\hline Cosmos 494 & $72043 \mathrm{~A}$ & 100.7 & 74.0 \\
\hline Meteor 12 & $72049 \mathrm{~A}$ & 102.8 & 81.2 \\
\hline Cosmos 500 & $72053 \mathrm{~A}$ & 94.8 & 74.0 \\
\hline Cosmos 514 & $72062 \mathrm{~A}$ & 104.3 & 82.9 \\
\hline Cosmos 516 & $72066 \mathrm{~A}$ & 104.5 & 64.8 \\
\hline Cosmos 521 & $72074 \mathrm{~A}$ & 104.9 & 65.8 \\
\hline Meteor 13 & $72085 \mathrm{~A}$ & 102.5 & 81.2 \\
\hline Cosmos 536 & $72088 \mathrm{~A}$ & 94.9 & 74.0 \\
\hline Cosmos 540 & $72104 \mathrm{~A}$ & 100.7 & 74.0 \\
\hline Cosmos 542 & $72106 \mathrm{~A}$ & 96.2 & 81.2 \\
\hline Cosmos 544 & $73003 \mathrm{~A}$ & 94.9 & 74.0 \\
\hline Cosmos 546 & $73005 \mathrm{~A}$ & 96.5 & 50.6 \\
\hline Cosmos 549 & $73010 \mathrm{~A}$ & 94.9 & 74.0 \\
\hline Meteor 14 & $73015 \mathrm{~A}$ & 102.5 & 81.2 \\
\hline Meteor 15 & $73034 \mathrm{~A}$ & 102.4 & 81.2 \\
\hline
\end{tabular}


Table VII (continued)

Forelgn Satellites Withrn the Shuttle Retrieval Envelope (11)

\begin{tabular}{|c|c|c|c|}
\hline Name & $\begin{array}{l}\text { International } \\
\text { Designation }\end{array}$ & $\begin{array}{l}\text { Perıod } \\
(\min )\end{array}$ & $\begin{array}{l}\text { Inclination } \\
\text { (deg) }\end{array}$ \\
\hline Cosmos 574 & $73042 \mathrm{~A}$ & 105.0 & 82.9 \\
\hline Cosmos 582 & $73060 \mathrm{~A}$ & 95.0 & 740 \\
\hline Cosmos 586 & $73065 \mathrm{~A}$ & 104.8 & 82.9 \\
\hline Cosmos 604 & $73080 \mathrm{~A}$ & 97.1 & 81.2 \\
\hline Intercosmos 10 & $73082 \mathrm{~A}$ & 95.2 & 73.9 \\
\hline Cosmos 610 & $73093 \mathrm{~A}$ & 95.0 & 74.0 \\
\hline Cosmos 614 & $73098 \mathrm{~A}$ & 100.6 & 74.0 \\
\hline Cosmos 626 & $73108 \mathrm{~A}$ & 104.0 & 65.4 \\
\hline Cosmos 627 & $73109 \mathrm{~A}$ & 105.0 & 82.9 \\
\hline Cosmos 628 & $74001 \mathrm{~A}$ & 104.8 & 82.9 \\
\hline Cosmos 631 & $74005 \mathrm{~A}$ & 95.1 & 74.0 \\
\hline Meteor 16 & $74011 \mathrm{~A}$ & 102.1 & 81.2 \\
\hline $\mathrm{UK}-\mathrm{X} 4$ & $74013 \mathrm{~A}$ & 101.1 & 97.8 \\
\hline Cosmos 648 & $74024 \mathrm{H}$ & 102.5 & 81.2 \\
\hline Cosmos 651 & $74029 \mathrm{~A}$ & 103.4 & 64.9 \\
\hline Cosmos 654 & $74032 \mathrm{~A}$ & 104.4 & 64.9 \\
\hline Intercosmos 11 & $74034 \mathrm{~A}$ & 94.5 & 505 \\
\hline Cosmos 655 & $74035 \mathrm{~A}$ & 95.1 & 74.0 \\
\hline Cosmos 661 & $74045 \mathrm{~A}$ & 95.0 & 74.0 \\
\hline Cosmos 662 & $74047 \mathrm{~A}$ & 90.5 & 70.8 \\
\hline Cosmos 663 & $74048 \mathrm{~A}$ & 104.8 & 82.9 \\
\hline Meteor 18 & $74052 \mathrm{~A}$ & 103.0 & 81.2 \\
\hline Cosmos 673 & $74066 \mathrm{~A}$ & 97.0 & 81.2 \\
\hline
\end{tabular}


Table VII (continued)

Foreıgn Sateliites Withın the Shuttle Retrıeval Envelope (11)

\begin{tabular}{|c|c|c|c|}
\hline Name & $\begin{array}{c}\text { International } \\
\text { Designation }\end{array}$ & $\begin{array}{l}\text { Period } \\
\text { (min) }\end{array}$ & $\begin{array}{l}\text { Inclination } \\
\text { (deg) }\end{array}$ \\
\hline ANS & $74070 \mathrm{~A}$ & 94.9 & 98.0 \\
\hline Cosmos 676 & $74071 \mathrm{~A}$ & 100.9 & 74.0 \\
\hline Cosmos 687 & $74076 \mathrm{~A}$ & 93.0 & 739 \\
\hline Cosmos 689 & 74079 A & 105.0 & 82.9 \\
\hline Meteor 19 & $74083 \mathrm{~A}$ & 102.4 & 81.1 \\
\hline Meteor 20 & 74099 A & 102.3 & 81.2 \\
\hline Cosmos 698 & $74100 \mathrm{~A}$ & 95.2 & 74.0 \\
\hline Cosmos 700 & $74105 \mathrm{~A}$ & 104.7 & 82.9 \\
\hline Salyut 4 & $74104 \mathrm{~A}$ & 90.9 & 51.5 \\
\hline Cosmos 699 & $74103 \mathrm{~A}$ & 92.6 & 65.0 \\
\hline Cosmos 707 & $75008 \mathrm{~A}$ & 95.0 & 74.0 \\
\hline Starlette & $75010 \mathrm{~A}$ & 104.1 & 49.8 \\
\hline Intercosmos 13 & $75022 \mathrm{~A}$ & 103.9 & 82.9 \\
\hline Meteor 21 & $75023 \mathrm{~A}$ & 102.5 & 81.2 \\
\hline Cosmos 723 & $75024 \mathrm{~A}$ & 103.7 & 64.7 \\
\hline Cosmos 724 & $75025 \mathrm{~A}$ & 103.0 & 65.5 \\
\hline Cosmos 726 & $75028 \mathrm{~A}$ & 104.6 & 82.9 \\
\hline Arzabat & $75033 \mathrm{~A}$ & 96.4 & 50.6 \\
\hline Cosmos 729 & $75034 \mathrm{~A}$ & 104.9 & 82.9 \\
\hline Castor & $75039 \mathrm{~B}$ & 99.0 & 29.9 \\
\hline Cosmos 744 & $75056 \mathrm{~A}$ & 97.0 & 81.2 \\
\hline Cosmos 749 & $75062 \mathrm{~A}$ & 95.1 & 74.0 \\
\hline Meteor 2 & $75064 \mathrm{~A}$ & 102.4 & 81.2 \\
\hline
\end{tabular}


Table VII (continued)

Forelgn Satellutes Within the Shuttle Retrieval Envelope (11)

\begin{tabular}{|c|c|c|c|c|}
\hline Name & & $\begin{array}{c}\text { International } \\
\text { Designation }\end{array}$ & $\begin{array}{l}\text { Perıod } \\
(m \geq n)\end{array}$ & $\begin{array}{l}\text { Inclination } \\
\text { (deg) }\end{array}$ \\
\hline Cosmos & 750 & $75067 \mathrm{~A}$ & 93.9 & 71.0 \\
\hline Cosmos & 752 & $75069 \mathrm{~A}$ & 94.5 & 65.8 \\
\hline Cosmos & 755 & $75074 \mathrm{~A}$ & 104.9 & 82.9 \\
\hline Cosmos & 756 & $75076 \mathrm{~A}$ & 972 & 81.2 \\
\hline KIKU & & $75082 \mathrm{~A}$ & 105.9 & 46.9 \\
\hline Meteor & 22 & $75087 \mathrm{~A}$ & 102.3 & 81.2 \\
\hline D2-B & & $75092 \mathrm{~A}$ & 96.8 & 37.1 \\
\hline Cosmos & 773 & $75094 \mathrm{~A}$ & 100.8 & 74.0 \\
\hline Cosmos & 778 & $75103 \mathrm{~A}$ & 104.8 & 82.9 \\
\hline Cosmos & 781 & $75109 \mathrm{~A}$ & 95.1 & 74.0 \\
\hline Cosmos & 783 & $75112 \mathrm{~A}$ & 100.9 & 74.0 \\
\hline Interc & osmos 14 & $75115 \mathrm{~A}$ & 105.1 & 73.9 \\
\hline Cosmos & 785 & $75116 \mathrm{~A}$ & 104.2 & 65.0 \\
\hline Meteor & 23 & $75124 \mathrm{~A}$ & 102.3 & 81.2 \\
\hline Cosmos & 787 & $76001 \mathrm{~A}$ & 95.2 & 74.0 \\
\hline Cosmos & 789 & $76005 \mathrm{~A}$ & 104.9 & 82.9 \\
\hline Cosmos & 790 & $76007 \mathrm{~A}$ & 95.2 & 74.0 \\
\hline Cosmos & 800 & $76011 \mathrm{~A}$ & 105.0 & 82.9 \\
\hline Cosmos & 801 & $76012 \mathrm{~A}$ & 94.7 & 70.9 \\
\hline Cosmos & 803 & $76014 \mathrm{~A}$ & 96.3 & 65.8 \\
\hline UME & & 76019 A & 105.1 & 69.6 \\
\hline Cosmos & 808 & $76024 \mathrm{~A}$ & 97.0 & 81.2 \\
\hline Cosmos & 812 & $76031 \mathrm{~A}$ & 95.1 & 74.0 \\
\hline
\end{tabular}


Table VII (contınued)

\begin{tabular}{lccc} 
Foreıgn Satellites Within the Shuttle Retrieval Envelope (II) \\
\hline Name & $\begin{array}{c}\text { Internatıonal } \\
\text { Designatıon }\end{array}$ & $\begin{array}{c}\text { Perıod } \\
\text { (mın) }\end{array}$ & $\begin{array}{c}\text { Inclination } \\
\text { (deg) }\end{array}$ \\
\hline Meteor 24 & $76032 \mathrm{~A}$ & 102.2 & 81.2 \\
Cosmos 816 & $76037 \mathrm{~A}$ & 94.5 & 65.8 \\
Meteor 25 & $76043 \mathrm{~A}$ & 102.3 & 81.2 \\
Cosmos 818 & $76044 \mathrm{~A}$ & 91.8 & 71.0 \\
Cosmos 822 & $76049 \mathrm{~A}$ & 94.4 & 74.0 \\
Cosmos 823 & $76051 \mathrm{~A}$ & 104.9 & 82.9 \\
Intercosmos 15 & $76056 \mathrm{~A}$ & 94.6 & 74.0 \\
Salyut 5 & $76057 \mathrm{~A}$ & 89.2 & 51.5 \\
Cosmos 834 & $76058 \mathrm{~A}$ & 88.9 & 81.3 \\
Cosmos 835 & $76060 \mathrm{~A}$ & 100.9 & 74.0 \\
Cosmos 836 & $76061 \mathrm{~A}$ & 89.4 & 65.0 \\
\hline
\end{tabular}

